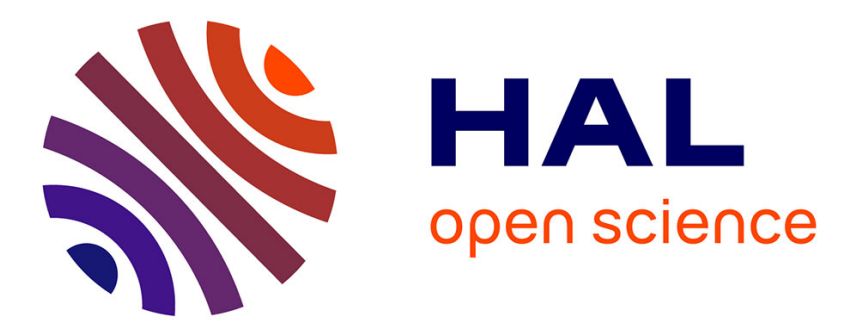

\title{
Modeling of wind gap formation and development of sedimentary basins during fold growth: application to the Zagros Fold Belt, Iran
}

Marine Collignon, Philippe Yamato, Sébastien Castelltort, Boris J.P. Kaus

\section{- To cite this version:}

Marine Collignon, Philippe Yamato, Sébastien Castelltort, Boris J.P. Kaus. Modeling of wind gap formation and development of sedimentary basins during fold growth: application to the Zagros Fold Belt, Iran. Earth Surface Processes and Landforms, 2016, 41 (11), pp.1521-1535. 10.1002/esp.3921 . insu-01358818

\section{HAL Id: insu-01358818 https://hal-insu.archives-ouvertes.fr/insu-01358818}

Submitted on 2 Sep 2016

HAL is a multi-disciplinary open access archive for the deposit and dissemination of scientific research documents, whether they are published or not. The documents may come from teaching and research institutions in France or abroad, or from public or private research centers.
L'archive ouverte pluridisciplinaire HAL, est destinée au dépôt et à la diffusion de documents scientifiques de niveau recherche, publiés ou non, émanant des établissements d'enseignement et de recherche français ou étrangers, des laboratoires publics ou privés. 
Modeling of wind gap formation and development of sedimentary basins during fold growth: application to the Zagros Fold Belt, Iran.

M.Collignon ${ }^{1,2}$, P.Yamato ${ }^{3}$, S.Castelltort ${ }^{4}$, B.J.P.Kaus ${ }^{5}$

1. Geological Institute, ETH Zurich, Switzerland.

2. Now at Centre for Earth Evolution and Dynamics (CEED), Postbox 1028 Blindern, 0315 Oslo, Norway.

3. Géosciences Rennes, Université de Rennes 1, CNRS, UMR 6118, Cedex 35042 , France.

4. Département des Sciences de la Terre, Rue des Maraîchers 13, 1205 Geneva, Switzerland.

5. Institute für Geowissenschaften, Johannes Gutenberg-Universität, Mainz, Germany.

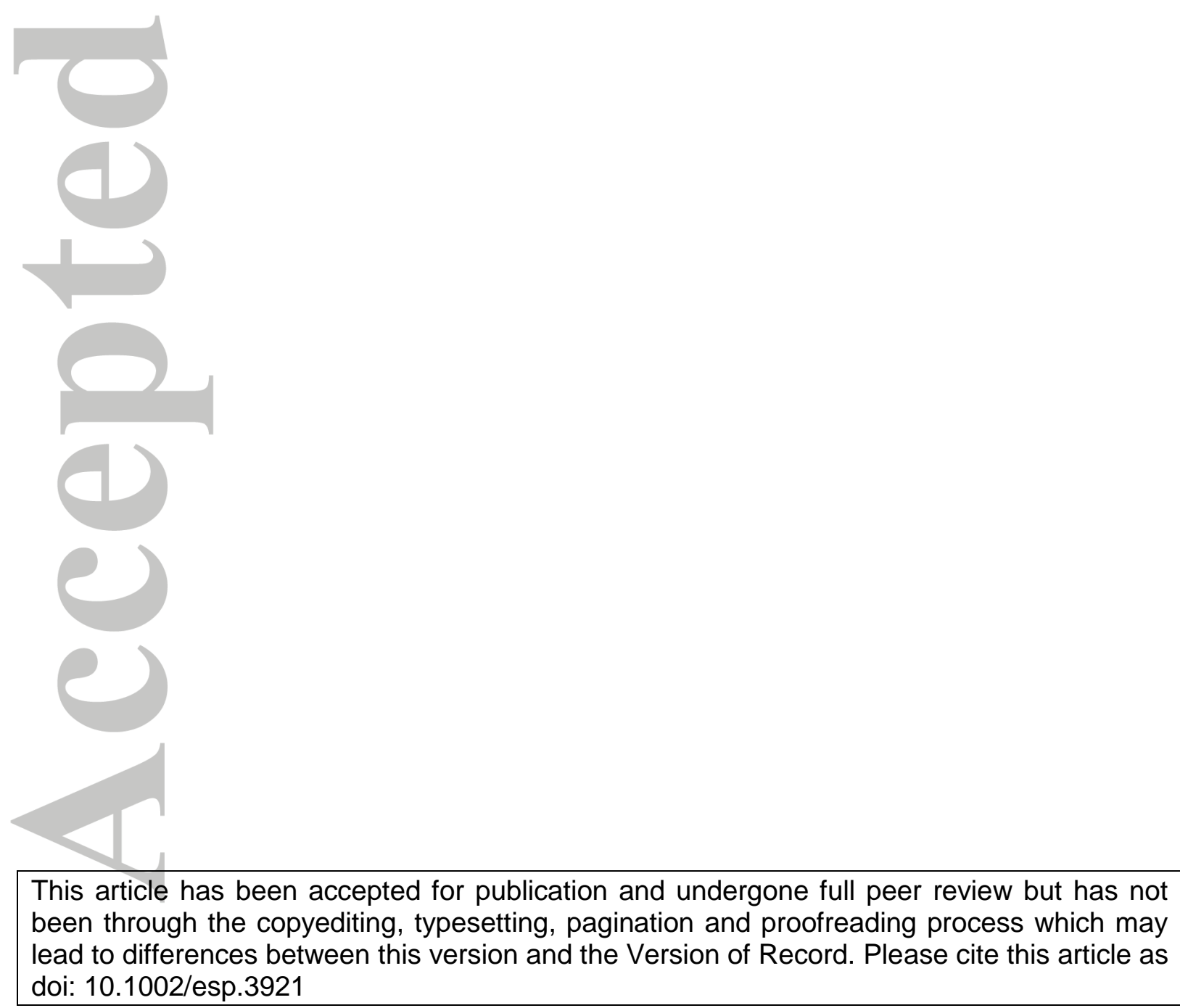




\section{Abstract}

Mountain building and landscape evolution are controlled by interactions between river dynamics and tectonic forces. Such interactions have been extensively studied, however a quantitative evaluation of tectonic/geomorphic feedbacks, which is imperative for understanding sediments routing within orogens and fold-and-thrust belts, remains to be undertaken. Here, we employ numerical simulations to assess the conditions of uplift and river incision necessary to deflect an antecedent drainage network during the growth of one, or several, folds. We propose that a partitioning of the river network into internal (endorheic) and longitudinal drainage arises as a result of lithological differences within the deforming crustal sedimentary cover. Using examples from the Zagros Fold Belt (ZFB), we show that drainage patterns can be linked to the non-dimensional incision ratio $R$ between successive lithological layers, corresponding to the ratio between their relative erodibilities or incision coefficients. Transverse drainage networks develop for uplift rates smaller than $0.8 \mathrm{~mm} . \mathrm{yr}^{-1}$ and low $R(-10<R<10)$. Intermediate drainage networks are obtained for uplift rates up to $2 \mathrm{~mm} . \mathrm{yr}^{-1}$ and large incision ratios $(\mathrm{R}>20)$. Parallel drainage networks and the formation of sedimentary basins occur for large values of incision ratio $(R>20)$ and uplift rates between 1 and $2 \mathrm{~mm} \cdot \mathrm{yr}^{-1}$. These results have implications for predicting the distribution of sediment depocenters in fold-and-thrust belts, which can be of direct economic interest for hydrocarbon exploration. They also put better constraints on the fluvial and geomorphic responses to fold growth induced by crustal-scale tectonics. 


\section{Introduction}

Landscape geomorphology and drainage patterns provide indirect information on tectonic activity (Alvarez, 1999; Bretis et al., 2011; Burbank et al., 1996; Castelltort and Simpson, 2006b; Keller et al., 1999; Oberlander, 1985; Tomkin and Braun, 1999; Walker et al., 2011; Wohl, 1993). Geomorphic markers such as wind gaps and river gaps (or transverse streams) have previously been used to define the style of deformation and to quantify both the rate and the direction of propagation of fault and fold segments (Bretis et al., 2011; Delcailleau et al., 2006; Keller et al., 1999; Ramsey et al., 2008; Vergés, 2007). River gaps (also termed water gaps) correspond to valleys that are carved during fold growth and that still host a flowing stream, whereas wind gaps constitute similar valleys that are presently dry (Fig. 1A). Deformation, climate and rock properties control the rates of rock and surface uplift, which shape landscapes. Understanding the interaction between these parameters and how they determine the formation of wind gaps is a question with direct implications for predicting the release of sediments (e.g., type and amount of material eroded, transported and redeposited) in local intramontane basins and at the outlet of fluvial basins (Gupta, 1997; Tucker and Slingerland, 1996), as well as for the evolution of river networks in orogens (Castelltort and Simpson, 2006a; Hovius, 1996). Folding disturbs the length and slope of sediment routing systems, by influencing the distribution of transverse and parallel rivers. Hence, sediments in streams parallel to structures are transported over longer distances and gentler slopes than those in transverse rivers. This increases the probability that sediments will be trapped en-route to sea-level in basins and topographic lows (Tucker and Slingerland, 1996), thereby potentially enhancing the buffering capacity of fluvial 
systems with respect to upstream tectonic or climatic signals (Allen, 2008a; Castelltort and Van Den Driessche, 2003).

Rivers in the Fars Province of the Zagros fold-and-thrust belt generally flow parallel to folds, with the exception of the Mand and Kul rivers, which remain transverse to the tectonic structures (Fig. 1B). These two main trunks delimit an internally drained region (IDR), north of the city of Lars (Fig. 1). Informally named the Razak region by Allen et al. (2013), the IDR was first identified by Mouthereau et al. (2007) and subsequently studied by Walker et al. (2011), and more recently by Lee (2015). Walker et al. (2011) identified dry valleys and wind gaps within several basins in the IDR, for which they proposed an antecedent river origin. Similarly, the present day longitudinal streams in the Coastal Fars presumably result from the deflection, by fold growth, of an antecedent transverse network (Fig.1; see also Lee, 2015; Mouthereau et al., 2012; Mouthereau et al., 2007; Ramsey et al., 2008; Walker et al., 2011). Alternatively, Lee (2015), proposed that the Razak IDR represents a series of formerly integrated lake basins, which have since dried up, possibly due to climatic aridification and tectonic activity. The wind gaps would then be former spillover points and interconnected basins would have been initiated by fold growth (Lee, 2015).

As such, the history of the IDR remains unclear (Lee, 2015; Walker et al., 2011). Furthermore, the reconstructions of Lee (2015), and Walker et al., 2011, are predominantly based on digital elevation model (DEM) analyses and do not take (physical) modeling into account. Using physical models may help to better understand and predict the behavior of both tectonic and surfaces processes, as well 
as the interactions between them. In the present work, we aim to investigate how river incision and tectonic surface activity interact to maintain the course of transverse rivers in the case of an antecedent or contemporaneous drainage network.

In order to address this issue, we employ a surface processes model (SPM), which considers the evolution of topographic surfaces modified by both erosion and sedimentation. The topographic surface is subjected to horizontal and vertical displacements according to a prescribed tectonic velocity field, representing shortening due to compression, and fold growth, respectively. We performed three sets of simulations in order to understand the interactions between fold growth, surface processes and drainage development. (1) In the first set of experiments we use a single layer of sediments with an infinite thickness, and test the influence of climate controlled erosion rate (river incision), fold growth rate and fold length. This set of simulations is used to select a range of appropriate values for the river incision coefficient for the next set of simulations, which employ two layers of rock with differing lithological properties. (2) In the second set of experiments, we investigate the influence of successive soft and resistant lithologies. (3) In the third set of experiments, we tentatively explore the role that the growth of several folds has on the drainage pattern. Only one parameter is changed for each simulation, to allow us to understand the relative influence of river incision, fold growth rate and fold length. Finally, results and limitations of the model were discussed and applied to the Razak IDR and more generally to the Zagros Fold Belt (ZFB). 


\section{Model and parameters}

The SPM employed here was initially developed for coupling surface processes with lithospheric and crustal dynamics (LaMEM Kaus et al., 2012; Kaus et al., 2016; Popov and Kaus, 2013) with a focus on the effects of surface processes (i.e. erosion and sedimentation) on fold dynamics at the scale of the fold-and-thrust belt (Collignon et al., 2015; Collignon et al., 2014). The model broadly follows the approach of Simpson and Schlunegger (2003) and is described in details in Collignon et al., (2014). A comparison to other existing SPMs (Braun and Sambridge, 1997; Tucker et al., 2001; Tucker and Slingerland, 1994; Willgoose et al., 1991a, b) was discussed in Collignon (2015). For the purpose of this study, the SPM works on top of a simple kinematic model to simulate fold growth. Both the SPM and the kinematic model are described in detail in the supplementary material (Appendix S1). The parameters used in this study are summarized in Table 1.

\subsection{Model design and boundary conditions}

\subsubsection{Single fold experiment}

The setup consists of an initial $100 \times 50 \mathrm{~km}^{2}$ smooth, incised surface tilted with a slope of $\sim 0.5^{\circ}$ in the $y$-direction (Fig. 2A). Both upstream and downstream edges are kept at their initial elevation throughout the entire simulation. We applied an initial surface roughness of $5 \mathrm{~m}$ to initiate incision by water runoff. The values, for both the initial regional slope and the initial surface roughness, were chosen to allow development of numerical river basins with aspect ratios in the range of those 
observed for natural drainage basins (Castelltort and Yamato, 2013). The numerical model has $500 \times 250$ elements in the $x$-and $y$-directions, respectively. Zero water and sediment fluxes are applied normal to the lateral boundaries (i.e. at $x=0$ and $x=$ $L x$, respectively), such that sediments leave the model only at the downstream edge of the model (when $y=0$ ). Compression is applied in the $y$-direction using a constant strain rate $\dot{\varepsilon}_{B G_{y}}$. The uplift function imposes the growth of a single anticline in the center of the numerical model with a variable fold wavelength and fold length in the $x$ - and $y$-directions, respectively. We used the same, spatially-variable, uplift function in all simulations, but considered cases in which the maximum uplift rate is either constant or variable through time (Fig. 2B-D), according to a Gaussian distribution (see Suppl. Mat., Appendix S1.2).

\section{Two layer models}

In the models that employed two layers, a 100 m thick layer with a given erodibility was placed on top of a layer of different erodibility and with an infinite thickness (Fig. $2 A)$. The incision ratio $(R)$ between these two layers is defined as:

$$
R=\frac{c_{u}}{c_{l}}
$$

where $c_{u}$ and $c_{l}$ are the erodibility coefficient of the upper $100 \mathrm{~m}$ thick layer and the lower layer, respectively (see table 1 for symbols and units). $R>1$ implies that sediments, which are relatively prone to erosion (e.g. marls and shales) are resting on top of a more resistant lithology (e.g. conglomerates), while $R<1$ represents the opposite case. 


\section{Time dependent uplifts}

In the simulations with two layers and time-dependent uplifts, we investigated the effects of the time span of fold growth $(\sigma)$ and the time at which the uplift rate is at a maximum $(\mu)$ on the persistence of transverse drainage networks for different maximum uplift rates $(q f)$.

\subsubsection{Three folds models}

In these models, we seek to understand the effects of an array of folds on the persistence of transverse drainage networks. The model (see App. S1, Suppl. Material) considers a larger domain $(60 \times 120 \mathrm{~km})$ and an uplift function that simulates the growth of three adjacent folds perpendicular to the $y$-direction of shortening (Table 2).

\subsection{Erosional and tectonic parameters}

We applied a compressive background strain rate (see eq. 9 in Suppl. Mat.) of $-5 \times 10^{-}$ ${ }^{15} \mathrm{~s}^{-1}$ in all simulations, giving convergent velocities in the range of those obtained by GPS measurements for the ZFB (Masson et al., 2007; Tatar et al., 2002) and similar to previous numerical simulations of folding that considered multilayer detachment systems (e.g. Collignon et al., 2014; Fernandez and Kaus, 2014; Yamato et al., 2011). Rainfall (see eq. 2 in Suppl. Mat.) was set to 0.3 m.yr ${ }^{-1}$, in accordance with annual precipitation rates measured in Iran (Masoodian, 2008). We assumed no major climate change to have occurred over the past $5 \mathrm{Ma}$ (Khadivi et al., 2012) and that rainfall was constant and homogeneous during the simulation. Additionally, we

did not consider any changes in precipitation rates related to altitude variations, 
(Garcia-Castellanos, 2007; Roe et al., 2003), which is acceptable for the lower Fars Province because of its overall low elevation (Masoodian, 2008). The powerexponent ( $m$, see eq. 3 in Suppl. Mat.) of water discharge is kept constant at 2, consistent with previous models (Graf, 1971; Simpson and Schlunegger, 2003) implying a strong non-linear dependency of the sediment discharge on water discharge. The hillslope diffusion coefficient ( $k$, see eq. 3 in Suppl. Mat.) was varied between $10^{-10}$ and $10^{-11} \mathrm{~m}^{2} \cdot \mathrm{s}^{-1}$, which is in the lower range of commonly used values for terrestrial systems (Armitage et al., 2011; Densmore et al., 2007; Howard, 1997). The parameters that were varied in the simulations were the maximum fold crest uplift rate ( $q f$, see eq. 8 in Suppl. Mat.) and the erodibility of rocks (c, see eq. 3 in Suppl. Mat.). We fixed the fold wavelength to $15 \mathrm{~km}$ according to previous studies (Mouthereau et al., 2007; Yamato et al., 2011). Anticlines in the ZFB are commonly particularly elongated, with an along-strike length of up to $80 \mathrm{~km}$. Although some degree of elongation may initially develop during fold growth, such geometry is usually interpreted to be the result of fold axis-parallel growth and linkage of smaller neighboring fold segments (Frehner, 2014; Grasemann and Schmalholz, 2012; Ramsey et al., 2008). Accordingly, the fold length and fold growth rates in our experiments were varied within the range of 20 to $80 \mathrm{~km}$, and 0.4 to $2 \mathrm{~mm} . \mathrm{yr}^{-1}$, respectively. The erodibility $(c)$ was varied between 0.1 and 50 .

\section{Results from parametric study}

\subsection{Models with a single layer and a constant surface uplift rate}

Results from all the simulations (> 200 in total) suggest that the drainage networks obtained after tectonic forcing can be classified into three main modes, based on the 
obtained drainage morphology with respect to the fold (Fig. 3A). We define the back of the fold as the upstream, north side of the fold. The front of the fold thus corresponds to the downstream, south side of the fold (Fig. 3A). The transverse incision mode is defined by a drainage pattern in which rivers incise across, and flow through, the growing fold. The drainage network at the back of the fold remains unaffected, or only slightly perturbed, with minor deflections close to the fold. In this mode, some rivers may be deflected and a wind gap may form, but the number of wind gaps always remains smaller than the number of through-going rivers. The intermediate incision mode is defined by both (i) streams incising within the growing fold at (or near) its tips and (ii) the presence of several wind gaps between the middle of the fold, or crest point, and the tips (Fig. 3A). The drainage network at the back of the fold is deviated and modified by the capture of adjacent streams. The spacing of transverse streams is larger in the intermediate incision mode than in the pure transverse incision mode, and the number of wind gaps is equal to, or larger than, the number of through-going rivers. The parallel incision mode describes a drainage network that is completely deviated around the growing fold (Fig. 3A). Many wind gaps are observed within the fold and at its tips. Deviations of the drainage network away from the fold are more pronounced at the back of the fold than at the front.

River deflection is independent of fold length and only results from the competition between surface uplift and fluvial incision (Fig. 4, Suppl. Mat., Table 1). Transitions from transverse to intermediate to parallel drainage networks occur for increasing maximum fold crest uplift rates $(q f)$ and/or for decreasing erodibility (c) (Fig. 4). Moreover, the transition from a transverse to intermediate drainage network, or from 
intermediate to parallel, is accompanied by an increase in horizontal distance between two through-going rivers (Fig. 4, Suppl. Mat. Table 1).

\subsection{Two-layer models}

In these models, we kept a constant erodibility (set so $c=1$ ) for the resistant lithology and varied the erodibility between 2 and 50 for the softer sediments. The choice of $c$ is based on the results of the previous set of simulations (section 3.1). We considered different shapes of uplift rate functions (Fig. 2B-D), and investigated maximal values for the maximum fold uplift rate, $q f$, ranging from 0.4 to $2 \mathrm{~mm} . \mathrm{yr}^{-1}$ (Table 2). We fixed the fold wavelength to $15 \mathrm{~km}$ and the fold length to $80 \mathrm{~km}$, as the latter has no influence on the drainage network.

In addition to "incision" modes, which describe the pattern of localized incision linked with active or defeated streams on the fold, we distinguished three erosional responses: 1) The maximum of erosion occurs at the fold, 2) the maximum of erosion occurs at the back of the fold and 3) a sedimentary basin forms at the back of the fold. Further in the text these three responses are referred as erosion modes, which describe the erosion pattern around the fold (Fig. 3B). The "maximum of erosion at the fold location" mode corresponds to the case where erosion reaches the lower layer at the fold location. The maximum erosion rate is thus located at the fold. The "maximum of erosion at the back of the fold" mode represents the case where the lower layer becomes exposed at the back of the fold, which is where the maximum erosion rates occur. The drainage network at the back of the fold is well connected and drains the north side of the fold. At this location, the rivers have a 
higher incision capacity through aggregation of drainage area, and the maximum of erosion coincides with the location of rivers and steepest local slopes. The two previous modes of erosion are characterized by a quasi-absence of significant ( $>50$ $\mathrm{m}$ in thickness) sedimentary deposits, in contrast to the third erosion mode (Basin at the back of the fold) for which deep (> $50 \mathrm{~m}$ in thickness) basins formed at the back of the fold. Such basins form during the growth of synclines and can either remain isolated or can connect to form a single wide $\left(>50 \mathrm{~km}^{2}\right)$ and deep $(>50 \mathrm{~m}$ in thickness) basin.

Transitions between modes of incision and modes of erosion are not gradual, and do not show a unidirectional trend. This suggests that the parameters $q f$ and $R$ are coupled, and one limits the influence of the other on the preservation of throughgoing rivers. Each incision and erosion mode is constrained by a set of values for both $q f$ and $R$ (Fig. 5A, Suppl. Mat. Table 2).

\subsubsection{Constant uplift rates}

Our results generally show that river incision and the resilience of transverse drainage networks (transverse and intermediate modes) are favored by low values of both $q f$ and $R$ (Fig. 5A, Suppl. Mat., Table 2). For $R>1$, a transition from a transverse to intermediate to parallel drainage network occurs with increasing values of $R$ and $q f$ (Fig. 5A, Suppl. Mat., Table 2). The number of wind gaps increases during successive transitions (Fig. 5A, Suppl. Mat., Table 2). For $R<1$, a transition from a transverse to intermediate drainage network is obtained with increasing values of $q f$ and/or decreasing values of $R$. In the case of a parallel drainage 
network, the streams at the back of the fold are deviated further northwards of the fold with an increased $q f$ and $R$.

Maximum erosion rates at the fold are favored by low values of $q f$ and $R$ (Fig. 5B, Suppl. Mat., Table 2). Transitions from maximum erosion at the fold to the back of the fold occur with an increasing $q f$ for $R<10$, whereas transitions from maximum erosion at the fold to the development of sedimentary basins at the back of the fold occur with an increasing $q f$ and/or $R$ for $R>10$ (Fig. 5B, Suppl. Mat., Table 2). Sedimentary basins at the back of the fold (erosion mode 3 ) become wider and deeper, and connect to form a single basin (Fig. 5B).

We do not observe the same transitions for the incision modes, suggesting that incision modes are not directly associated with a specific erosion mode (Figs. 4-5). This might be due to the position of through-going rivers in the intermediate drainage network. If, for example, rivers only incise the tips of the fold, the drainage network at the back of the fold is deviated around the fold and erosion migrates upstream, leading to the location of maximum erosion rates at the back of the fold. If a stream crosses the crest of the anticline, or if through-going rivers incise between the fold crest point (middle) and the tips, the drainage network at the back of the fold is less deviated than in the previous case and maximum erosion rates may be located at the fold.

Overall, the persistence of a drainage network is favored when the surface has a resistant lithology, whereas wide and deep sedimentary basins develop when the surface layer consists of soft sediments (Figs. 6-7). If $R<1$, the river needs time to 
incise the substrate and through-going rivers are widely spaced from each other (Fig. 6A). Rivers keep pace through the growing fold with increasing time and uplift (Fig. 6A). The maximum erosion rate occurs at the fold location (Fig. 7A). If $R>1$, incision by rivers is fast and the distance between through-going rivers is small (Fig. 6B). Rivers are progressively deflected around anticlines with increased fold uplift and many wind gaps form on the fold (Fig. 6B). Rivers at the back of the fold are deviated northward, further away from the fold with time and uplift. As a consequence, sedimentary basins develop at the back of the fold and increase in size and number with uplift,(Fig. 7B).

\subsubsection{Time-dependent uplift rates}

The maximum uplift rate $(q f)$ is computed for different values of both $q f_{\text {gauss }}(0.6-2$ mm.yr $\left.{ }^{-1}\right)$ and $q f_{b g}\left(0-0.2 \mathrm{~mm} . \mathrm{yr}^{-1}\right)$, varying values of $\mu(0.05-1.5 \mathrm{Ma})$ and $\sigma(0.125-0.5$ Ma) (Table 2 and eq. (8) in Suppl. Mat.). In order to limit the number of simulations and to decipher the effects of $\sigma$ and $\mu$, we fixed $R$ at representative values, for which transitions from transverse to intermediate drainage or from intermediate to parallel drainage were observed with an increasing $q f$. We tested both the case where a resistant lithology lays on top of soft sediments $(R=0.05)$ and the contrary situation $(R=20)$.

Influence of the time of maximum uplift rate $(\mu)$

We set $\sigma$ to $0.125 \mathrm{Ma}$ to investigate the role of the time of maximum uplift rate, $\mu$. The parameter $\mu$ influences the erosion and incision modes only if it occurs during 
early stages of the drainage network development $(\sim 0.1 \mathrm{Ma})$ and for a restricted range of uplifts (Fig. 8A, Suppl. Mat., Table 3).

For $R=0.05$ and $q f<2$, transition from a transverse to intermediate drainage network occurs with increasing $\mu$, between 0.05 and $0.5 \mathrm{Ma}$ (Fig. 8A, Suppl. Mat., Table 3). The transition from maximum of erosion at the fold to the back of the fold occurs with increased $\mu$ between 0.5 and $0.75 \mathrm{Ma}$ and for all investigated values of qf (Fig. 8C, Suppl. Mat. Table 3). The earlier rivers are deflected around the fold, the more the drainage network at the back of the fold is connected and the higher its incision capacity is.

For $R=20$, a transition from an intermediate to parallel drainage network is observed for $q f \sim 1.8 \mathrm{~mm} . \mathrm{yr}^{-1}$ (Fig. 8B, Suppl. Mat., Table 3). Wide and deep basins (erosion mode 3) form for all investigated values of $q$ (Fig. 8D, Suppl. Mat., Table 3). The streams at the back of the folds are deviated northwards away from the fold with decreasing $\mu$ and increasing $q f$, leading to the development of a unique wide and connected basin.

Influence of fold growth duration $(\sigma)$

We set $\mu$ to 1 to test the influence of $\sigma$. Rivers tend to be deflected with increasing $q f$ and $\sigma$ (Fig. 9A, B, Suppl. Mat., Table A4). However for $\mathrm{R}=0.05$, a river is still cutting through the anticline at high values of $q f(\geq 1.6)$ and $\sigma(\geq 0.5)$. 
For $R=0.05$, the drainage network at the back of the fold is not well connected. Erosion cannot migrate upstream and remains located at the folds. The lower layer is more exposed at the surface, at the fold location with increasing $q f$ and $\sigma$, suggesting possible higher erosion rates. This erosion pattern is obtained for values of $q f$ and $\sigma$ at which a river cuts the fold at its crest (Fig. 9A, C, Suppl. Mat. Table A4). Syntectonic sedimentation at the front of the fold is enhanced with increased $\sigma$ and $q f$.

For $R=20$, rivers at the back of the fold are deviated northward further away from the fold with increased $q f$ and $\sigma$, resulting in the development of a wide and connected basin at the back of the fold (Fig. 9D, Suppl. Mat., Table A4).

Influence of the shape of the uplift rate function

Wind gap formation and river incision mainly depend on the cumulative uplift during the simulation. We performed simulations that have comparable cumulative uplifts but for which the uplift rates were prescribed in different manners: in one case, the uplift rate was kept constant, whereas in two other cases uplift rates were time dependent, which better represents the dynamics of fold growth (Suppl. Mat. Fig. A1A). The time dependent uplift follows a Gaussian distribution, and thus the uplift rate in our simulation initially increases, after which it decreases.

At constant uplift rates, rivers are deflected rather late in time, (at ca. 1.5 Ma after the beginning of the experiment) and the distance between through-going rivers and 
wind gaps is large (Suppl. Mat. Fig. A1B). At $2 \mathrm{Ma}$, a single wind gap is observed in the center part of the fold (Suppl. Mat. Fig. A1B).

For time-dependent uplift, rivers are deflected before $1 \mathrm{Ma}$ and the distance between through-going rivers and wind gaps is small (Suppl. Mat. Fig. A1C,D). At $2 \mathrm{Ma}$, several wind gaps exist in the center part of the fold (Suppl. Mat. Fig. A1C,D). For the time dependent uplift rates, when a small background uplift rate is employed (Suppl. Mat. Fig. A1D), the distance between initially through-going rivers is larger than when no background uplift rate is prescribed (Suppl. Mat. Fig. A1C).

\subsection{Multi-fold models}

In the subsequent set of simulations, we used a two-layer setup and fixed $q f$ to 0.6 mm.yr ${ }^{-1}$, the fold length to $80 \mathrm{~km}$ and the wavelength to $15 \mathrm{~km}$. We tested cases for $R=20$ and $R=0.05$ for comparison with the single-fold simulations shown in Figures

\section{6 and 7.}

When several folds are considered, the modeled rivers may be deflected in the upstream part (Fig. 10), leading to the development of sedimentary basins at the back of the fold (Fig. 11). However, the rivers may still be able to incise the anticline in the middle and downstream parts. Incision occurs in more downstream parts than if only one fold is considered (Fig. 6).

With an increasing incision ratio $R$ between two successive layers, the rivers are more deflected and incision is only possible at the tips of the anticline in the most 
downstream part (Fig. 10B). For high $R$ values ( 20), the basins that developed at the back of the folds (Fig. 11B) are wider, deeper and more connected than in the single fold experiment (Fig. 7B).

\section{Discussion}

\subsection{General observations}

Results from our parametric study showing that river deflection occurs with increasing uplift rates or decreasing erodibility are in good agreement with field observations (Burbank et al., 1996; Delcailleau et al., 2006; Delcailleau et al., 1998; Keller et al., 1999; Ramsey et al., 2008). Our study also shows that the evolution of uplift rather than its absolute value, greatly affects the sustainability of transverse rivers. However, our results also show that alternating soft and resistant layers change this systematics and the magnitude of the maximum uplift rate plays a role as well. This suggests that the influence of each individual parameter is difficult to separate in order to predict the morphology of a drainage network or the presence of sedimentary basins. Nevertheless, our parametric study allows us to evaluate for which range of the tested parameters transverse drainage is dominated by erosional processes or by tectonics. In the latter case, it also allows us to decipher whether the duration of the tectonic perturbation or its magnitude played a key role in shaping the landscape. In order to better constrain the transition between erosion and incision modes, other values of the investigated parameters should be systematically tested. Once simple relationships between drainage network, sedimentary basins and erosional parameters are constrained for given uplift rates, the morphology of the 
drainage network and uplift rates estimated from field data can be compared to models to constrain the lithology or erosional parameters, and vice versa. Simple lithological and tectonic control on drainage networks, and their limits derived from our parametric study are discussed below.

\subsubsection{Lithological control on drainage network}

The sustainability of a drainage network depends on (i) the local erodibility capacity required to compensate local tectonic uplift and (ii) the ability of the river to transport sediments away from the erosion point (Braun and Sambridge, 1997; Howard, 1994; Howard and Kerby, 1983; Whipple and Tucker, 1999). Rivers that flow on a soft substrate are quickly loaded with sediments and lose their incision capacity, which decreases even more once the river reaches a deeper, less erodible lithology. Consequently, in such a configuration, the river cannot compensate for the tectonic uplift and is deflected. In the case where rivers flow over a resistant lithology, the river load is much smaller than in the previous case. The river still has the capacity to transport sediments when the sediment supply increases, even after reaching a deeper, more erodible lithology, and is therefore still able to incise through the fold. Our results show that this is limited to constant uplift rates equal to, or lower than, $0.8 \mathrm{~mm} . \mathrm{yr}^{-1}$ and for an incision ratio value between 0.5 and 5 in alluvial rivers. For higher incision ratios, the sediment load is too high, and the river can no longer incise. 


\subsubsection{Structural control on the preservation of transverse drainage network}

Sustainability of transverse drainage networks is intrinsically linked to the ability of rivers to quickly respond to tectonic forcing (Allen, 2008b; Castelltort and Van Den Driessche, 2003; Tucker and Slingerland, 1997; Whipple and Tucker, 1999, 2002). In this study, river incision depends on the relationship between the time of fold growth and the time of response of the alluvial system, which is controlled by the diffusion coefficient. Our results show that rivers are deflected when folds grow rapidly. When uplift rate variations are smooth or nonexistent, rivers have time to adjust their profile and can continue to incise the fold. If, on the contrary, uplift rates change sharply, rivers do hot have time to adjust their profile and are thus deflected (Fig. 12).

When a soft lithology is present at the surface, rivers are almost systematically deflected, for the time span of fold growth investigated. This suggests that in the case of time-dependent uplift rates, the persistence of through-going rivers is controlled by the incision ratio between the two layers, the time span of fold growth, the time at which the uplift rate is maximum and the magnitude of the maximum uplift rate. Therefore, clear relationships between the morphology of the drainage network and one or two of these parameters are not easy to isolate and further work is required to constrain them.

SPMs predict that erosion has a power dependence on the upstream drainage area. The capacity of the river to incise growing folds is thus also related to the connectivity of the drainage area at large scales (Simpson, 2004). The simultaneous growth of several folds builds several topographic barriers to transverse streams. A 
large-scale transverse drainage network has a higher probability to be disconnected than if it meets only one fold, resulting in a diminution of the contributing drainage area, and thus, of the incision and the transport efficiency. This discontinuity of the drainage network has some consequences on the long-range sediment transport and the sediment budget in the fold-and-thrust belt. Sediments are trapped in intramontane basins, and may never reach the outlets.

\subsection{Comparison with previous work}

In all of our simulations, the tectonic perturbation occurred either simultaneously with or after the emplacement of the drainage network. Therefore, our models only considered the case of antecedence, and not superposition or a combination of both (Alvarez, 1999; Mazzanti and Trevisan, 1978; Oberlander, 1985). In the case of superposition, Oberlander (1985) proposed that a thick pile of sediments buried prior to folding allows the development of a transverse drainage network. These folds are then exhumed by erosion and the rivers, emplaced in soft sediments, which continually incise the anticlines and form steep gorges through them (Fig. 1A). However, results from our models show that soft sediments located on top of resistant lithologies favor river deflections. We considered the kinematic component of the deformation, where folds grow by limb lengthening or rotation and where the fold tips are fixed (Dahlstrom, 1990; Poblet and Hardy, 1995), thus ignoring fold lengthening (i.e. growth along the fold axis). Therefore, geomorphic and drainage network characteristics associated with fold elongation, such as a decrease in wind gap elevation towards the fold tip (Keller et al., 1999), the fan-shaped tributaries on the flank of the anticlines (Keller and DeVecchio, 2013; Ramsey et al., 2008) or 
curved wind gaps (Bretis et al., 2011), were not reproduced in our simulations. Also, as suggested by Keller (1999), models that consider limb lengthening are unlikely to produce two wind gaps or a wind and water gap from the same river. Instead, a river defeated by surface uplift in these models, is deflected around the tips of the fold, and leaves behind a single wind gap. However, fold elongation should not affect the results of this study on the prediction of wind gaps, because the preservation of through-going rivers or their deflection are controlled by the vertical competition between surface uplift and incision rates.

Many previous studies focused on sediment discharge and river capacity transport changes, as well as on drainage basin reorganization due to tectonic or climatic forcing (Tucker and Slingerland, 1996; Tucker and Slingerland, 1997; Tucker and Whipple, 2002; Whipple and Tucker, 1999, 2002). Some of these studies may refer to wind gaps (e.g. Tucker and Slingerland, 1996) but they did not systematically investigate the effect of surface uplift vs. river incision. Furthermore, even though some models consider a regolith layer above the bedrock (e.g. Tucker and Hancock, 2010; Tucker and Slingerland, 1997), they usually do not consider several lithologies with different river incision coefficients. In our study, we only focused on predicting the persistence of a transverse drainage network during fold growth and systematically investigated the conditions of surface uplift vs. incision ratio between two successive soft and strong layers. 


\subsection{Applications of our study and implications}

4.3.1. Evolution of the drainage network in the ZFB and formation of the Razak IDR.

Large outcrops of the fluvial Agha Jari and Bakhtiari formations are mainly found in the southeast and southwest of the Fars Province, where the transverse Mand and Kul rivers flow (Fig. 1B). Model results show that wide and deep sedimentary basins develop at the back of the fold, when rivers are deflected by fold growth and flow parallel to anticlines. This suggests that the Mand and Kul rivers are younger than the Agha Jari and Bakhtiari formations, which have been deposited by streams longitudinal to folds. Nowadays rivers generally flow longitudinal to folds, with the exception of these two main trunks. Walker et al. (2011) proposed that the Razak IDR and the present day drainage result from the deflection of former transverse streams due to differential uplifts, possibly during a phase of fold tightening at $\sim 2-3$ Ma (Mouthereau et al., 2007b; Mouthereau et al., 2012). However, the IDR of the Fars Province is not rapidly deforming presently (Talebian and Jackson, 2004), contrary to regions of lower elevation closer to the coast, where the deformation is mainly concentrated (Oveisi et al., 2007; Oveisi et al., 2009) and where transverse streams are also present. This suggests that processes other than uplift may explain the formation of these internally drained basins. Based on the results of our models, we propose that the horizontal and vertical distribution of soft and resistant lithologies within the belt, and thus the incision ratio between these two successive formations may also explain the deflection of rivers. The transverse Mand and Kul rivers are indeed incising the resistant Bakhtiari conglomerates, which are lying on the soft Agha Jari marls $(R<1)$. Contrastingly, longitudinal streams generally incise 
the Agha Jari marls that rest on top of the Asmari limestone or the soft quaternary deposits that rest on the Bakhtiari conglomerates $(R>1)$ (Fig. 1B).

\section{Timing and onset of folding.}

The evolution of the drainage network involves several stages of folding or uplift and considers a rather uniform fold growth through the entire fold-and-thrust belt. In our model, we consider that folds grow simultaneously over a time span of 1 to $2 \mathrm{Ma}$. This time span of fold growth is consistent with a recent magnetostratigraphic study (Ruh et al., 2014), which estimated that a single fold in the Fars Province developed within 1 to $1.5 \mathrm{Ma}$, and was initiated at $3.8 \mathrm{Ma}$. Although some studies assume homogeneous folding to have occurred (e.g. Fernandez and Kaus, 2014; Yamato et al., 2011), the deformation history in the Zagros Fold Belt might be more complex (e.g. Mouthereau et al., 2012). The onset of folding has been estimated with magnetostratigraphic measurements of progressive unconformities within the Agha Jari and Bakhtiari formations (Emami, 2008; Homke et al., 2004 ; Khadivi et al., 2010; Ruh et al., 2014). The Agha Jari formation was supposedly deposited during folding, whereas the Bakhtiari fluvial conglomerates, unconformable on the Agha Jari formation, have been previously interpreted as late to post folding sediments (Falcon, 1974; James and Wynd, 1965; Stocklin, 1968). The onset of deformation in the Simply Folded Zone has been estimated at 5-8 Ma (Homke et al., 2004; Emami, 2008; Ruh et al., 2014) and possibly earlier (Hessami et al., 2001; Khadivi et al., 2010). Recent studies demonstrated that the fluvial wedgetop sediments (comprising the Razak, Agha Jari, and Bakhtiari formations) are diachronous across the Zagros, becoming progressively younger from the north towards the Persian Gulf in the south (Homke et al., 2004 ; Khadivi et al., 2010; Pirouz et al., 2015). Hence, the timing and 
duration measured on growth strata in the Fars by Ruh et al. (2014) are not compatible with a homogeneous fold growth in the Zagros Simply Folded Belt. Our study constrained the condition of uplift versus river incision for a single fold in the range of the time span of fold growth in the Zagros, but did not consider the full deformation history of the area. We have not considered several stages of folding or uplift, and considered a homogeneous deformation in the models with several folds, which is not fully compatible with the magnetostratigraphic data. In this study, we did not consider the full deformation history, in order to simplify the model. Taking into account the full deformation history would imply considering more parameters and consequently possibly more complex models. Results obtained from models that consider deformation prescribed in a mechanical manner (Collignon et al., 2014; Ruh et al., 2013) may be different from those obtained from kinematic models. The present model has some limitations, and may fail to consider a complex deformation pattern. However, it allows a direct focus on the first order relationship between the morphology of the drainage network and erosion or uplift rates without any disturbance provided by other external parameters.

\subsubsection{Potential constraints for the erodibility of rocks in the ZFB}

Results from our numerical simulations allow us to estimate a range of incision ratios, $R$, for the folds in the Fars Province. The drainage network in the Fars Province is rather longitudinal and streams are often deflected around the anticlines, or locally incise their extremities (Fig. 13A). This drainage morphology is characteristic of intermediate and parallel drainage networks. Large sedimentary basins developed in synclines (e.g., the Bakhtiari formation in the Fars front, in 
coastal regions). The maximum erosion occured in between folds in synclines, in the ZFB. Fold growth rates between 0.3 and $0.6 \mathrm{~mm} . \mathrm{yr}^{-1}$ were estimated for the Qarah, Dalu and Takteh anticlines (Fig. 13B). The core of these anticlines exposes the resistant Asmari limestones, while the soft sediments of the Agha Jari and Gachsaran formations are the main lithologies around the Qarah and Dalu anticlines (see Fig. 1B), suggesting that $R>1$ (Fig. 13B). These anticlines are cut at their tips by rivers, a characteristic of an intermediate drainage network (Fig. 13B). The Mand river is cutting the Takteh anticline at its tip (Fig. 13A) and the Bakhtiari formation is exposed around the fold. This suggests an intermediate drainage network with $R<1$ (Fig. 13B). Ages and incision rates obtained from cosmogenic nuclides measurements of terraces were used to infer fold uplift rates and horizontal shortening rates (Mouthereau et al., 2007). Erodibility indicates a structural uplift rate of $\sim 0.7 \pm 0.2 \mathrm{~mm} . \mathrm{yr}^{-1}$ and a shortening rate of $\sim 1.2 \pm 0.5 \mathrm{~mm} \cdot \mathrm{yr}^{-1}$ across the Khartang/Poshtu structures (Oveisi et al., 2009). The uplift rates are similar to those obtained by Mouthereau et al. (2007). Incision rates for the Halikan anticlines have been estimated between 0.8 and $3.3 \mathrm{~mm} . \mathrm{yr}^{-1}$, leading to shortening rates across the structures of between 1.0 and $5 \mathrm{~mm} . \mathrm{yr}^{-1}$. The Mand anticline accommodates most of the frontal deformation with 3-4 mm.yr $\mathrm{r}^{-1}$ (Oveisi et al., 2009). According to Oveisi et al. (2009), uplift rates are sensibly similar to incision rates for marine terraces, suggesting that the Mand and Halikan anticlines (Fig. 13B) have uplift rates at least 2 to 3 times faster than for the folds in the Central Fars (Mouthereau et al., 2007). These folds are located in the frontal part of the Fars, where the Bakhtiari conglomerates are thick (Yamato et al., 2011; Mouthereau et al., 2012). The tips of these folds are cut by the Mand river. These observations are in favor of an intermediate drainage network, with $R<1$ (Fig. 13B). Considering that limestones 
and conglomerates have more or less the same erodibility coefficient, we can use a ratio 1, in the case when the Bakhtiari conglomerates rest directly on the top of the Asmari limestones. If the layer is thick, the river may not have reached a deeper layer, and $R=1$. This could be the case for the Mand and Halikan anticlines in the coastal Fars, where the Bakhtiari Formation can reach up to $1 \mathrm{~km}$ in thickness (Yamato et al., 2011).

\section{Conclusion}

We presented a set of numerical experiments designed to explore the conditions of uplift rates versus river incision in deflecting syn-deformation drainage during the growth of one or several folds. We have identified 3 incision modes: transverse, intermediate and parallel, and we have distinguished 3 erosion modes: maximum erosion rates at the fold, maximum erosion rates at the back of the fold and deposition of large sedimentary basins at the back the fold. The simulations suggest that transverse drainage networks occur for uplift rates (qf) up to $0.8 \mathrm{~mm} . \mathrm{yr}^{-1}$ and incision ratio $(R)$ values ranging between 0.5 and 5 . Intermediate drainage networks are obtained for uplift rates up to $2 \mathrm{~mm}_{\mathrm{yr}} \mathrm{r}^{-1}$ and incision ratio up to 20 . Parallel drainage networks and the formation of sedimentary basins occur for large values of incision ratio (> 20) and uplift rates around 1-2 mm. $\mathrm{yr}^{-1}$.

Although this study focused primarily on the Zagros Fold Belt, the outcomes have implications for other foreland basins and fold-and-thrust belts. If the uplift rates are known for a specific erosion or incision mode, it is then possible to determine the incision ratio between two successive layers and vice-versa. This relationship paves 
the way for future work, both numerical and field-based. Incision rates are usually poorly constrained and further studies will be needed to confirm the first order relationship, proposed here, between incision and uplift rates and the geomorphology of the drainage network. This study also pointed out the importance of successive erodibilities on the river transport capacity, and by extension on its incision capacity. Further studies could quantify the erodibility of rocks in the field to obtain more constrained parameters that may be later employed in the numerical models. Finally, further numerical studies could consider the effect of employing a mechanical formulation of the deformation on the prediction of transverse drainage and test if direct relationships between uplift and incision rates can be derived.

\section{Acknowledgements}

M. Collignon was funded by the European Union FP7 Marie Curie ITN "TOPOMOD", contract no. 26517, and later the ERC Grant agreement nํ308126. B. Kaus was funded by the ERC Starting grant 258830. S. Castelltort acknowledges SNF grant No 200021-146822. The authors are thankful to Jean-Pierre Burg for the discussions and for providing the field picture for Figure 1A. Two anonymous reviewers and an anonymous associate editor are thanked for their helpful and constructive comments. Finally, the authors thank Abigail L. Bull for improving the syntax of the manuscript. 


\section{References:}

Allen, A. P., 2008a, From landscapes into geological history: Nature, v. 451, p. 274-276.

Allen, M., Saville, C., Blanc, E., Talebian, M., and Nissen, E., 2013, Orogenic plateau growth: Expansion of the Turkish-Iranian Plateau across the Zagros fold-andthrust belt: Tectonics, v. 32, p. 171-190.

Allen, P., 2008b, Time scales of tectonic landscapes and their sediment routing systems: Geological Society, London, Special Publications, v. 296, p. 7-28.

Alvarez, W., 1999, Drainage on evolving fold-thrust belts: a study of transverse canyons in the Apennines: Basin Research, v. 11, p. 267-284.

Armitage, J. J., Warner, N. H., Goddard, K., and Gupta, S., 2011, Timescales of alluvial fan development by precipitation on Mars: Geophysical research letters, v. 38, p. 6.

Braun, J., and Sambridge, M., 1997, Modelling landscape evolution on geological time scales: a new method based on irregular spatial discretization: Basin Research, v. 9 , p. 27-52.

Bretis, B., Bartl, N., and Graseman, B., 2011, Lateral fold growth and linkage in the Zagros fold and thrust belt (Kurdistan, NE Iraq): Basin Research, p. 16.

Burbank, D., Meigs, A., and Brozović, N., 1996, Interactions of growing folds and coeval depositional systems: Basin Research, v. 8, p. 199-223.

Castelltort, S., and Simpson, G., 2006a, Growing mountain ranges and quenched river networks Surface Geosciences (Geomorphology), v. 338, p. 1184-1193.

-, 2006b, River spacing and drainage network growth in widening mountain ranges Basin Research, p. 267-276.

Castelltort, S., and Van Den Driessche, J., 2003, How plausible are high-frequency sediment supply-driven cycles in the stratigraphic record ?: Sedimentary Geology, v. 157, p. 3-13.

Castelltort, S., and Yamato, P., 2013, The influence of surface slope on the slope of river basins: comparison between nature and numerical landscape simulation: Geomorphology, v. 191, p. 71-79.

Collignon, M., 2015, Interactions between surface processes and fold growth in foldand-thrust belts: application to the Zagros Fold Belt [PhD: ETH Zürich.

Collignon, M., Fernandez, N., and Kaus, B. J. P., 2015, Influence of surface processes and initial topography on lateral fold growth and fold linkage mode: Tectonics, v. 34, p. 24pp.

Collignon, M., Kaus, B. J. P., May, D. A., and Fernandez, N., 2014, Influence of surface processes on fold growth during 3-D detachment folding: Geochemistry, Geophysics, Geosystems, v. 15, no. 8, p. 3281-3303.

Dahlstrom, C. D. A., 1990, Geometric constraints derived from the law of conservation of volume and applied to evolutionary models for detachment folding: AAPG Bulletin, v. 74, p. 336-344.

Delcailleau, B., Carozza, J.-M., and Laville, E., 2006, Recent fold growth and drainage development: the Janauri and Chandigarh anticlines in the Siwalik foothills, northwest India: Geomorphology v. 76, p. 241-256.

Delcailleau, B., Deffontaines, B., Floissac, L., Angelier, J., Deramond, J., Souquet, P., Chu, H. T., and Lee, J. F., 1998, Morphotectonic evidence from lateral propagation of an active frontal fold; Pakuashan anticline, foothills of Taiwan: Geomorphology, v. 24, p. 263-290. 
Densmore, A. L., Allen, A. P., and Simpson, G., 2007, Development and response of a coupled catchment fan system under changing tectonic and climatic forcing: Journal of geophisical research, v. 112, p. 16.

Emami, H., 2008, Foreland propagation of folding and structure of the Mountain Front Flexure in the Pusht-e Kuh arc (NW Zagros, Iran) [PhD: Univ. de Barcelona, 118 p.

Falcon, N., 1974, Southern Iran: Zagros Mountains, in Spencer, A., ed., MesozoicCenozoic Orogenic Belts, Volume 4: London, Geological Society Special Publications, p. 199-211.

Fernandez, N., and Kaus, B. J. P., 2014, Fold interaction and wavelength selection in 3D models of multilayer detachment folding: Tectonophysics, v. 632, p. 199-217.

Frehner, M., 2014, 3D fold growth rates: Terra Nova, v. 26, p. 417-424.

Garcia-Castellanos, D., 2007, The role of climate during high plateau formation. Insights from numerical experiments: Earth and Planetary Science Letters, v. 257, p. 372390.

Graf, W. H., 1971, Hydraulics of Sediment Transport, New-York, Mc Graw-Hill.

Grasemann, B., and Schmalholz, S. M., 2012, Lateral fold growth and fold linkage: Geology, v. 40.

Gupta, S., 1997, Himalayan drainage patterns and the origin of fluvial megafans in the Ganges foreland basin Geology, v. 25, p. 11-14.

Hessami, K., Koyi, H. A., Talbot, C. J., Tabasi, H., and Shabanian, E., 2001, Progressive unconformities within an evolving foreland fold-thrust belt, Zagros Mountains: Journal of Geological Society, v. 158, p. 969-981.

Homke, S., Vergés, J., Garcés, M., Emami, H., and Karpuz, R., 2004 Magnetostratigraphy of Miocene-Pliocene Zagros foreland deposits in the front of the Push-e Kush Arc (Lurestan Province, Iran): Earth and Planetary Science Letters, v. 225, p. 397410.

Hovius, N., 1996, Regular spacing of drainage outlets from linear mountain belts Basin Research, v. 8, p. 29-44.

Howard, A. D., 1994, A detachment-limited model of drainage basin evolution: Water Resources Research, v. 30, p. 2261-2285.

-, 1997, Badland morphology and evolution: interpretation using a simulation model: Earth surface processes and landforms, v. 22, p. 211-227.

Howard, A. D., and Kerby, G., 1983, Channel changes in badlands: Geological Society of America Bulletin, v. 94, p. 739-752.

James, G. A., and Wynd, J. G., 1965, Stratigraphic nomenclature of Iranian oil consortium agreement area: AAPG Bulletin, v. 49, p. 2162-2245.

Kaus, B. J. P., Popov, A., and May, D. A., Recent Progress in modelling 3D lithospheric deformation, in Proceedings EGU Spring meeting, Vienna, 2012, Volume 14.

Kaus, B. J. P., Popov, A. A., Beaumann, T. S., Püsök, A. E., beauville, A., Fernandez, N., and Collignon, M., Forward and inverse modelling of lithospheric deformation on geological timescales, in Proceedings NIC Symposium 2016 - Proceedings2016, Volume 48, NIC Series.

Keller, E. A., and DeVecchio, D. E., 2013, Tectonic geomorphology of active folding and development of transverse drainages in Schroder, J., and Owen, L. A., eds., Treatise on Geomorphology, Volume 5: San Diego, Tectonic Geomorphology, p. 129-147. 
Keller, E. A., Gurrola, L., and Tierney, T. E., 1999, Geomorphic criteria to determine direction of lateral propagation of reverse faulting and folding Geology, v. 27, no. 515-518.

Khadivi, S., Mouthereau, F., Barbarand, J., Adatte, T., and Lacombe, 0., 2012, Constraints on palaeodrainage evolution induced by uplift and exhumation on the southern flank of the Zagros-Iranian Plateau: Journal of the Geological Society, London, v. 169 , p. 83-97.

Khadivi, S., Mouthereau, F., Larrasoaña, J.-C., Vergés, J., Lacombe, O., Khademi, E., Beamud, E., Melinte-Dobrinescu, M., and Suc, J.-P., 2010, Magnetochronology of synorogenic Miocene foreland sediments in the Fars arc of the Zagros Folded Belt (SW Iran): Basin Research, v. 22, p. 918-932.

Lee, J., 2015, Reconstruction of ancestral drainage pattern in an internally draining region, Fars Province, Iran: Geol. Mag., v. 152, no. 5, p. 830-843.

Masoodian, S. A., 2008, On Precipitation Mapping in Iran: Journal of Humanities The University of Isfahan, v. 30, no. 2, p. 69-80.

Masson, F., Anvari, M., Djanour, Y., Wapersdorf, A., Tavakoli, F., Daignieres, M., Nankali, H., and Van Gorp, S., 2007, Large-scale velocity field and strain tensor in Iran inferred from GPS measurements: new insight for the present-day deformation pattern within NE Iran: Geophysical Journal International, v. 170, no. 1, p. 436440.

Mazzanti, R., and Trevisan, L., 1978, Evoluzione della rete idrografica nell'Apennino Centro-Settentrionale: Geo. Fis. Din. Quat., v. 1, p. 55-62.

Mouthereau, F., Lacombe, O., and Vergés, J., 2012, Building the Zagros collisional orogens: timing, strain distribution and dynamics of Arabia/Eurasia plate convergence: Tectonophysics, v. 532-535, p. 27-60.

Mouthereau, F., Tensi, J., Bellahsen, N., Lacombe, O., De Boigrollier, T., and Kargar, S., 2007, Tertiary sequence of deformation in a thin-skinned/thick-skinned collision belt: The Zagros Folded Belt (Fars, Iran): Tectonics v. 26.

Oberlander, T. M., 1985, Origin of drainage transverse to structures in orogens. , in Morisawa, M., and Hack, J. T., eds., Tectonic Geomorphology, Proceedings of the 15 th Annual Binghampton Geomorphological Symposium, Volume 15, Allen and Unwin, p. 155-182.

Oveisi, B., Lavé, J., and Van der Beek, P., 2007, Rates and processes of active folding evidenced by Pleistocene terraces at the central Zagros front (Iran), in Lacombe, O., Lavé, J., Roure, F., and Vergès, J., eds., Thrust Belts and Foreland Basins: New York, Springer-Verlag "Frontiers in Earth Sciences", p. 265_285.

Oveisi, B., Lavé, J., Van der Beek, P., Carcaillet, J., Benedetti, L., and Aubourg, C., 2009, Thick- and thin-skinned deformation rates in the central Zagros simple folded zone (Iran) indicated by displacement of geomorphic surfaces Geophysical Journal International, v. 176, p. 627-654.

Pirouz, M., Simpson, G., and Chiaradia, M., 2015, Constraint on foreland basin migration in the Zagros mountain belt using Sr isotope stratigraphy: Basin Research, p. 115.

Poblet, J., and Hardy, S., 1995, Reverse modelling of detachment folds; applicaiton to the Pico del Aguila anticline in the South Central Pyrenees (Spain): Journal of Structural Geology v. 17, p. 1707-1724.

Popov, A., and Kaus, B. J. P., LaMEM (Lithospheric and Mantle Evolution Model): advancing a staggered-grid finite difference version of the code, in Proceedings EGU Spring meeting, Vienna, 2013, Volume 15. 
Ramsey, L. A., Walker, R. T., and Jackson, J., 2008, Fold evolution and drainage development in the Zagros mountains of Far provinces, SE Iran.: Basin Research, v. 20 p. $23-48$.

Roe, G. H., Montgomery, D. R., and Hallet, B., 2003, Orographic precipitation and the relief of mountain ranges: Journal of Geophysical Research, v. 108, no. B6, p. 1511- 15-12.

Ruh, J. B., Gerya, T. V., and Burg, J. P., 2013, High-resolution 3D numerical modeling of thrust wedges: Influence of décollement strength on transfer zones: Geochemistry Geophysics Geosystems, v. 14, no. 4, p. 25.

Ruh, J. B., Hirt, A. M., Burg, J. P., and Mohammadi, A., 2014, Forward propagation of the Zagros Simply Folded Belt constrained from magnetostratigraphy of growth strata: Tectonics, v. 33, p. 1534-1551.

Simpson, G., 2004, Dynamic interactions between erosion, deposition, and threedimensional deformation in compressional fold belt setting: Journal of geophisical research, v. 109, p. 13.

Simpson, G., and Schlunegger, F., 2003, Topographic evolution and morphology of surfaces evolving in repsonse to coupled fluvial and hillslope sediment transport: Journal of geophysical research, v. 108, p. 16p.

Stocklin, J., 1968, Structural history and tectonics of Iran: a review: American Association of Petroleum Geologist Bulletin, v. 52, p. 1223-1258.

Talebian, M., and Jackson, J., 2004, A reappraisal of earthquake focal mechanisms and active shortening in the Zagros mountains of Iran: Geophysical Journal International, v. 156, p. 506-526.

Tatar, M., Hartzfeld, D., Martinod, J., Walpersdorf, A., Ghafori-Astiany, M., and Chéry, J., 2002, The present-day deformation of the Central Zagros from GPS measurements: Geophysical research letters, v. 29, p. 19-27.

Tomkin, J. H., and Braun, J., 1999, Simple models of drainage reorganisation on a tectonically active ridge system: New Zealand Journal of Geology and Geophysics v. 42, p. 1-10.

Tucker, G. E., and Hancock, G. R., 2010, Modelling landscape evolution Earth surface processes and landforms v. 35, p. 28-50.

Tucker, G. E., Lancaster, S. T., Gasparini, N. M., Bras, R. L., and Rybarczyk, S. M., 2001, An object-oriented framework for distributed hydrologic and geomorphic modeling using triangulated irregular networks Computer \& Geosciences, v. 27, p. 959973.

Tucker, G. E., and Slingerland, R., 1994, Erosional dynamics, flexural isostasy, and longlived escarpments: a numerical modeling study: Journal of Geophysical Research, v. 99, p. 12,229-212,243.

Tucker, G. E., and Slingerland, R., 1996, Predicting sediment flux from fold and thrust belts: Basin Research v. 8, p. 329-349.

Tucker, G. E., and Slingerland, R., 1997, Drainage basin response to climate change: Water Resources Research, v. 33, p. 2031-2047.

Tucker, G. E., and Whipple, K. X., 2002, Topographic outcomes predicted by stream erosion models: sensitivity analysis and intermodel comparison Journal of Geophysical Research, v. 107, p. 16.

Vergés, J., 2007, Drainage responses to oblique and lateral thrust ramps: a review, in Nichols, G., Paola, C., and Williams, E. A., eds., Sedimentary processes, environments and basins: a tribute to Peter Friend, Volume 38, International Association of Sedimentologists, p. 29-47. 
Walker, R. T., Ramsey, L. A., and Jackson, J., 2011, Geomorphic evidence for ancestral drainage patterns in the Zagros Simple Folded Zone and growth of the Iranian plateau: Geological Magazine v. 148, p. 901-910.

Whipple, K. X., and Tucker, G. E., 1999, Dynamics of the stream-power river incision model: Implications for height limits of mountain range, landscape response timescales, and research needs.: Journal of Geophysical Research, v. 104, no. 661674.

-, 2002, Implications of sediment-flux-dependent river incision models for landscape evolution: Journal of Geophysical Research, v. 107, p. 20.

Willgoose, G., Bras, R. L., and Rodriguez-Iturbe, I., 1991a, A Coupled Channel Network Growth and Hillslope Evolution Model 1. Theory Water Resources Research, v. 27, no. 7, p. 1671-1684.

-, 1991b, Results from a new model of river basin evolution: Earth surface processes and landforms, v. 16, p. 237-254.

Wohl, E. E., 1993, Bedrock channel incision along Picanniny Creek, Australia: J. Geol. , v. 749-761, p. 749-761.

Yamato, P., Kaus, B., Mouthereau, F., and Castelltort, S., 2011, Dynamic constraints on the crustal-scale rheology of the Zagros fold belt, Iran: Geology v. 39, p. 814-818.

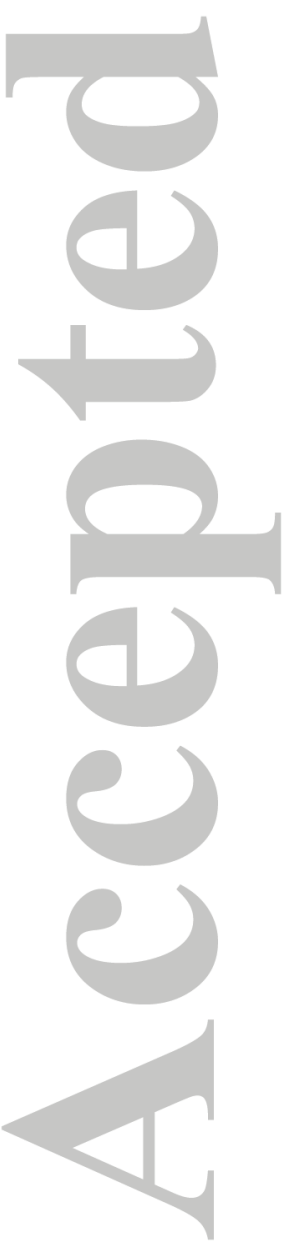


Table 1: parameters used by the numerical model. Units are given in SI.

\begin{tabular}{|c|c|c|}
\hline Symbol & Unit & Definition \\
\hline & $\mathrm{m}$ & initial dimensions of the model in $\mathrm{x}$ and $\mathrm{y}$ directions \\
\hline$x, y, z$ & $\mathrm{~m}$ & coordinates \\
\hline nelx, nely & & number of elements in $\mathrm{x}$ and $\mathrm{y}$ \\
\hline$H_{\max }$ & $\mathrm{m}$ & maximum initial elevation \\
\hline$h_{0}$ & $\mathrm{~m}$ & initial roughness of the surface processes model \\
\hline$q_{s e}$ & $m^{2} \cdot s^{-1}$ & surface sediment discharge \\
\hline & $\mathrm{m}^{2} \cdot \mathrm{s}^{-1}$ & surface water discharge \\
\hline 6 & $\left(m^{2} \cdot s^{-1}\right)^{1-n}$ & fluvial incision \\
\hline . & $m^{2} \cdot s^{-1}$ & hillslope diffusion \\
\hline$m$ & & exponent for dependency of sediment transport on fluid discharge \\
\hline$\alpha$ & $m \cdot s^{-1}$ & annual rainfall \\
\hline$\beta$ & & regional slope $\left(H_{\max } / L y\right)$ \\
\hline$x_{-}$fold $i$ & $\mathrm{~m}$ & $x$ coordinate of the i-th fold center \\
\hline$y_{-}$fold $i_{i}$ & $\mathrm{~m}$ & $y$ coordinate of the i-th fold center \\
\hline$D_{D}$ & $s^{-1}$ & background strain rate \\
\hline$\mu$ & s & expected value (gaussian function), time of maximum fold growth \\
\hline$\sigma$ & $\mathrm{s}$ & standard deviation (gaussian function), controls the time span of fold growth \\
\hline$q f$ & $m \cdot s^{-1}$ & maximum fold growth rate (anticline crest) \\
\hline$q f_{B G}$ & $m \cdot s^{-1}$ & background fold growth rate (gaussian function) \\
\hline$q f_{\text {gauss }}$ & $m \cdot s^{-1}$ & maximum fold growth rate for the gaussian function \\
\hline$t$ & s & time \\
\hline
\end{tabular}


Table 2: Values of parameters used in simulations. ${ }^{*}$ indicates the values used in the simulations with three folds.

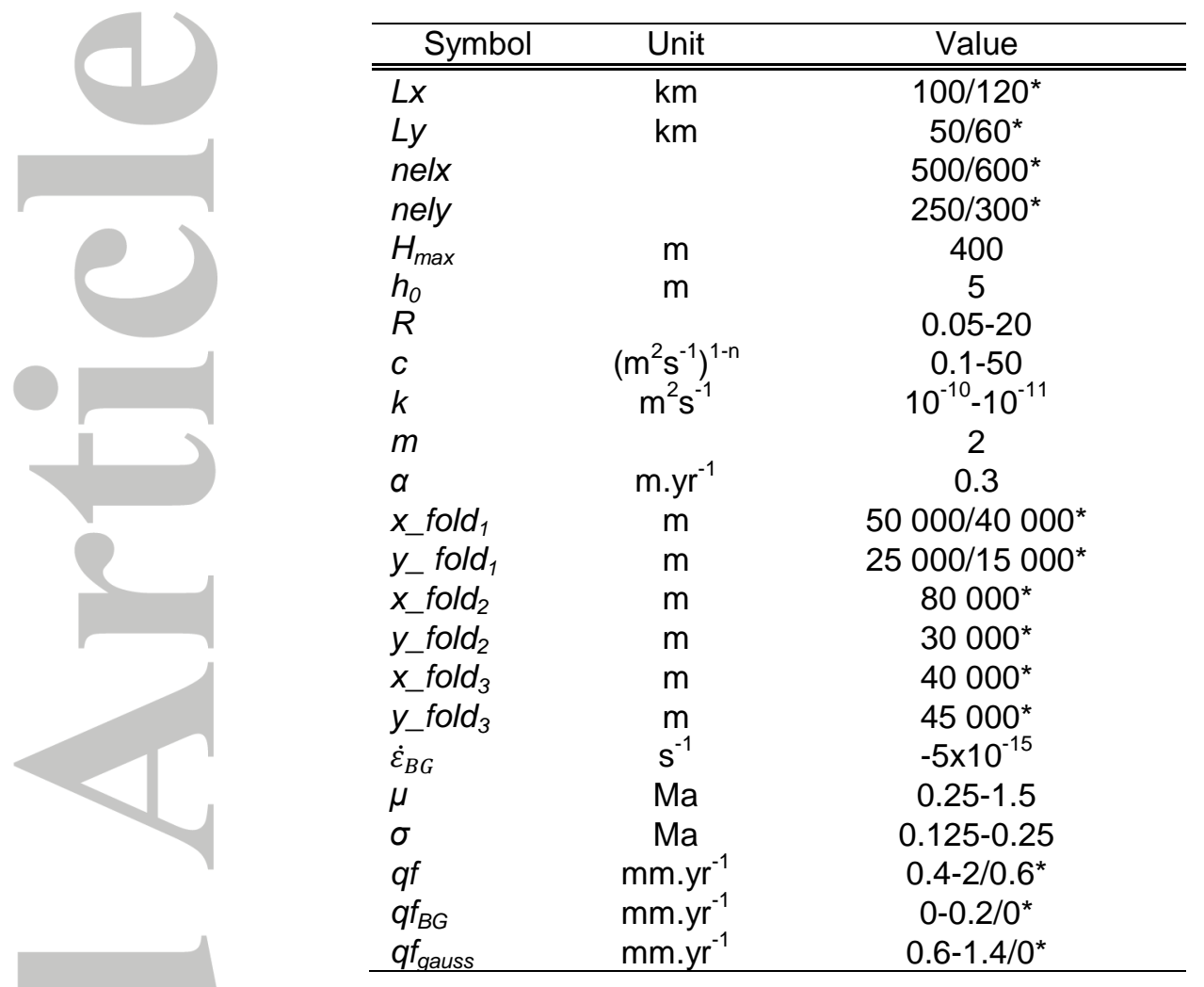

This article is protected by copyright. All rights reserved. 


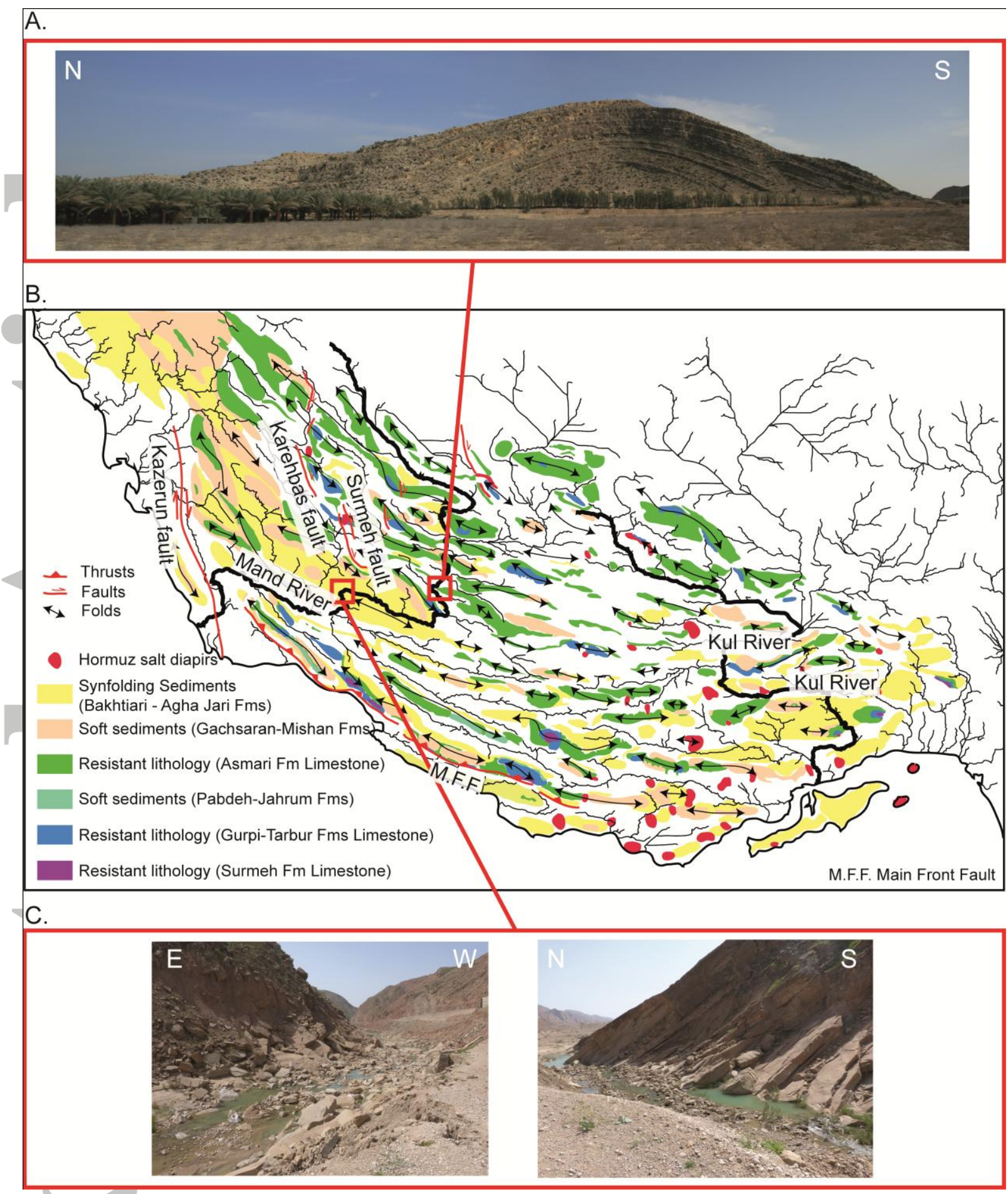

Figure 1: A. Wind gap at the tip of an anticline in the Fars Province (ZFB, Iran). 28¹9'15.42"N, $53^{\circ} 02^{\prime} 45.84^{\prime \prime}$. Image courtesy of Jean-Pierre Burg. B. Synthetic map of the Fars Province showing the main tectonic structures (faults, anticlines), drainage network and lithologies. C. Water gap in the Fars Province (ZFB, Iran). 28¹8'40. 09”N, 52²4'32.19”E.

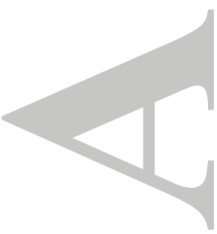

This article is protected by copyright. All rights reserved. 
A.

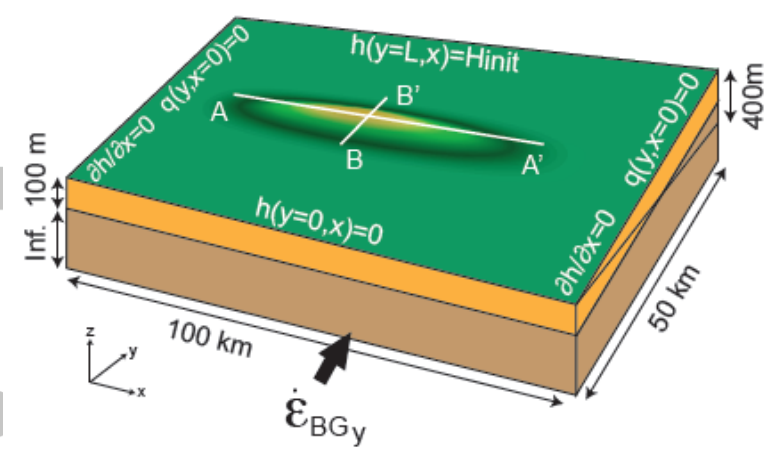

C. Constant uplift through time
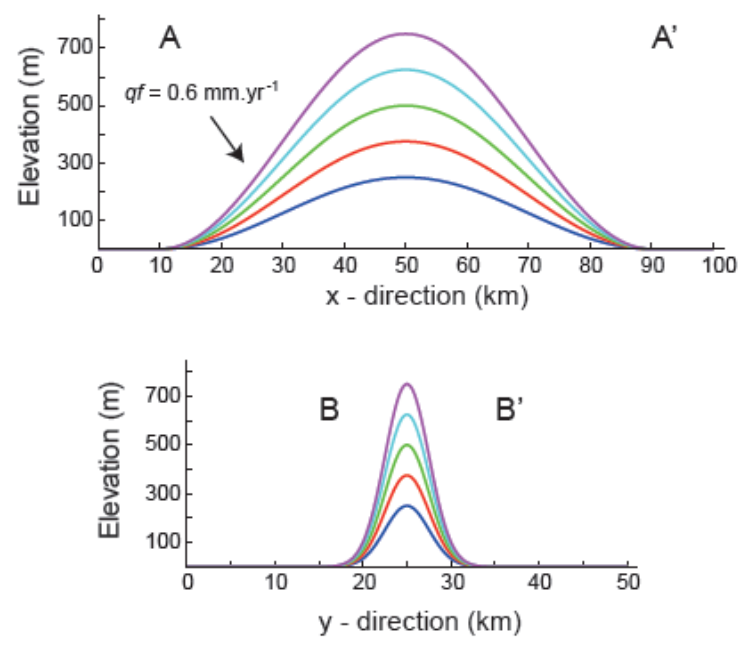

B.

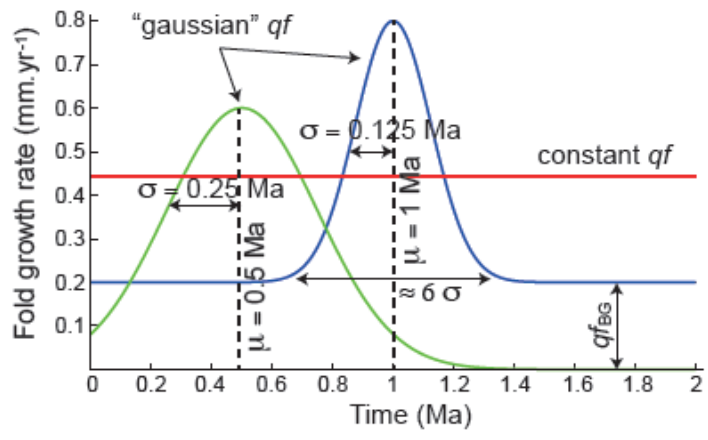

D. Variable uplift through time

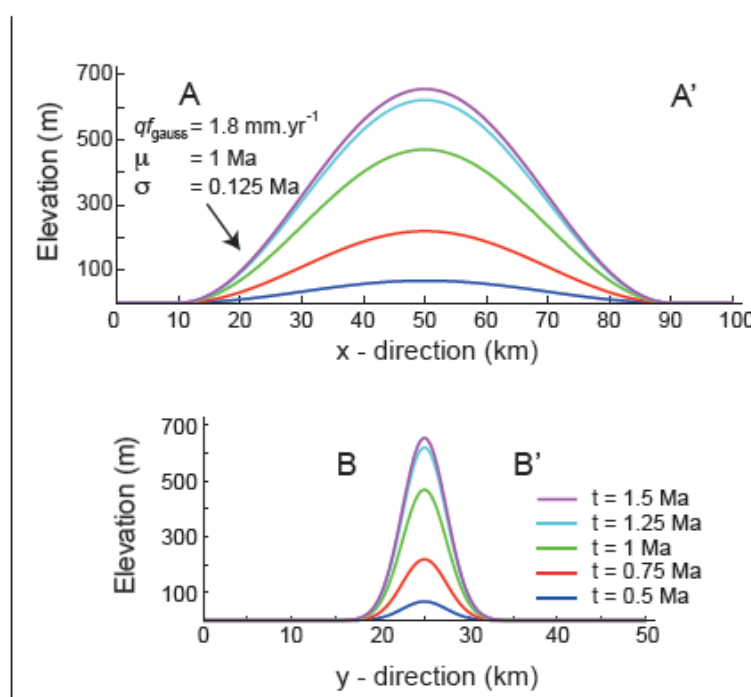

Figure 2: A. Initial and boundary conditions. The model consists in two layers with different fluvial incision parameters, $c$. The upper layer has a thickness of $100 \mathrm{~m}$, while the second is supposed to have an infinite thickness. B. Constant and time-dependent uplifts used in the simulations. C. Evolution of topographic transects for a constant uplift through time. D. Evolution of topographic transects for variable uplift through time. 


\section{A. Incision modes}

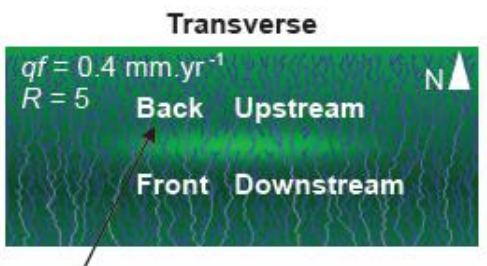

Straight, nearly not affected drainage network at the back of the fold. Numerous through-going rivers
Intermediate

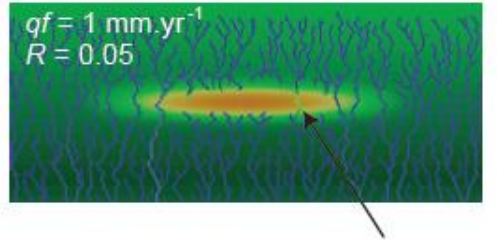

Deflection of rivers behind the fold. Incision at the tips.

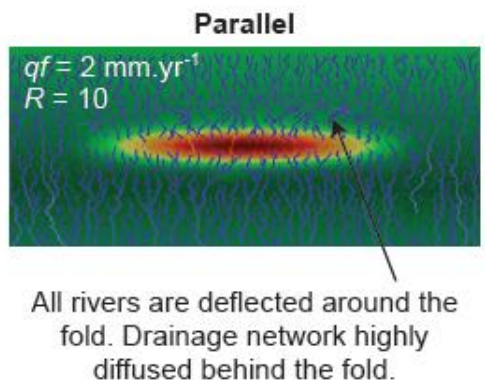

\section{B. Erosion modes}

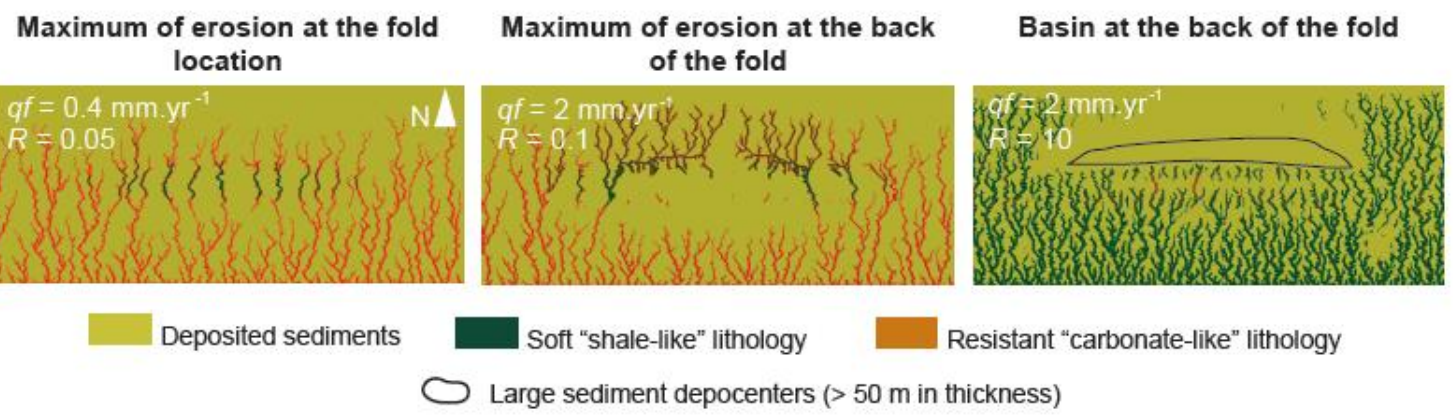

Figure 3: A. Different incision modes observed in our simulations. B. Different erosion modes observed in our simulations. 


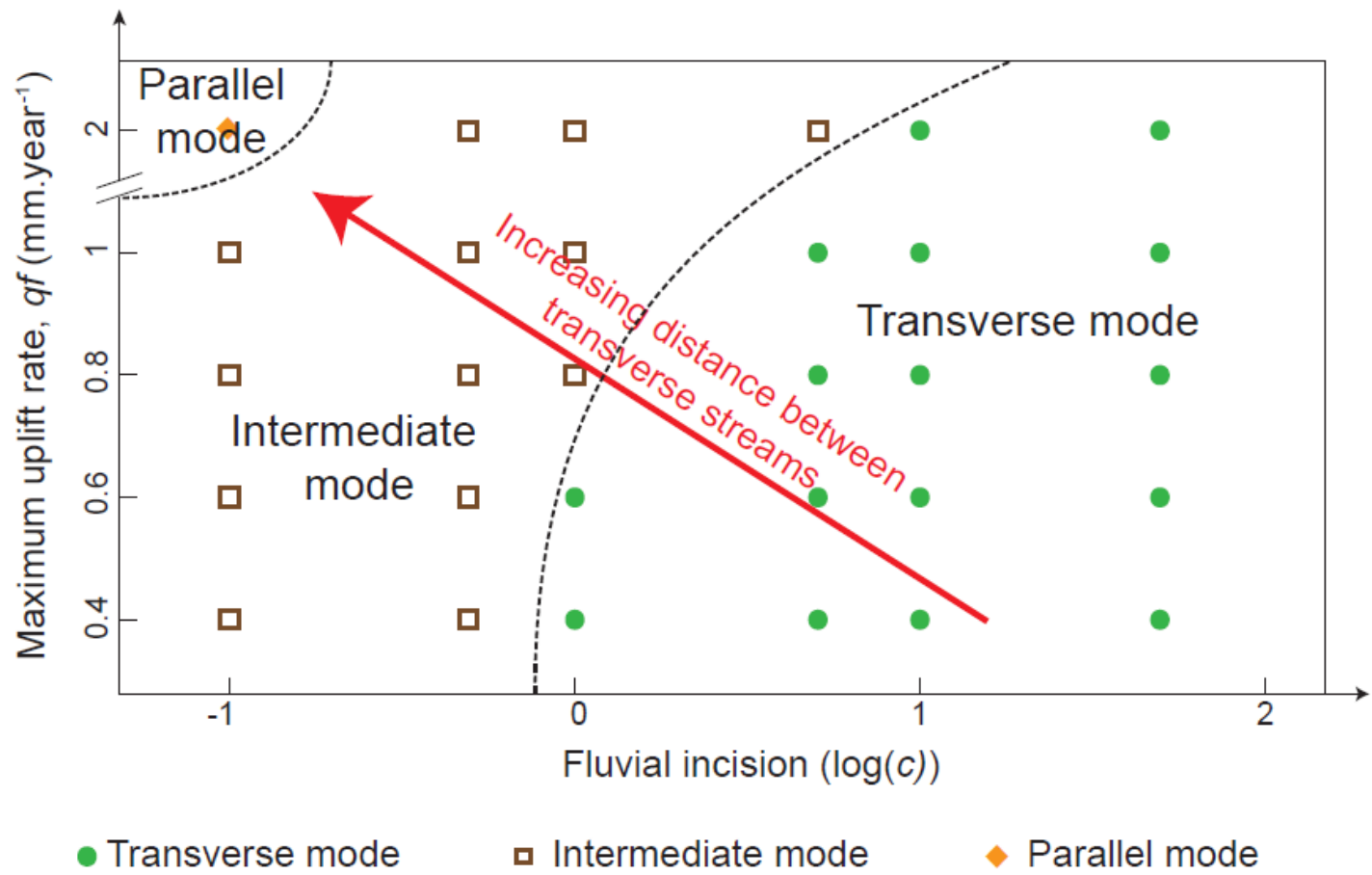

Figure 4: Distribution of the different drainage network modes for different conditions of uplift and fluvial incision (Transverse mode: full green circle, Intermediate mode: brown square, Parallel mode: yellow diamonds). The dotted lines represent the transition from one mode to another and have been constrained by numerical simulations, taken after $1 \mathrm{Ma}$. Each point represents a numerical simulation. 
A.
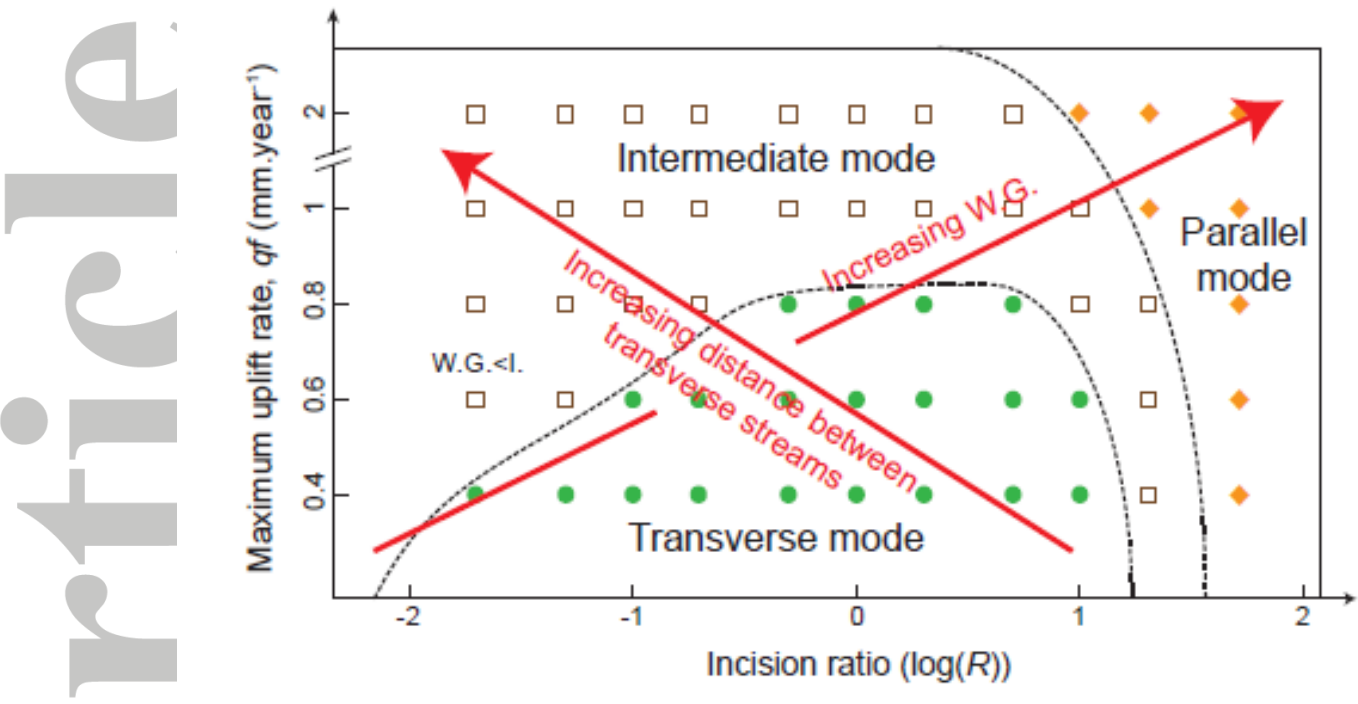

- Transverse mode $\quad$ Intermediate mode $\quad$ Parallel mode

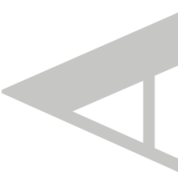

B.

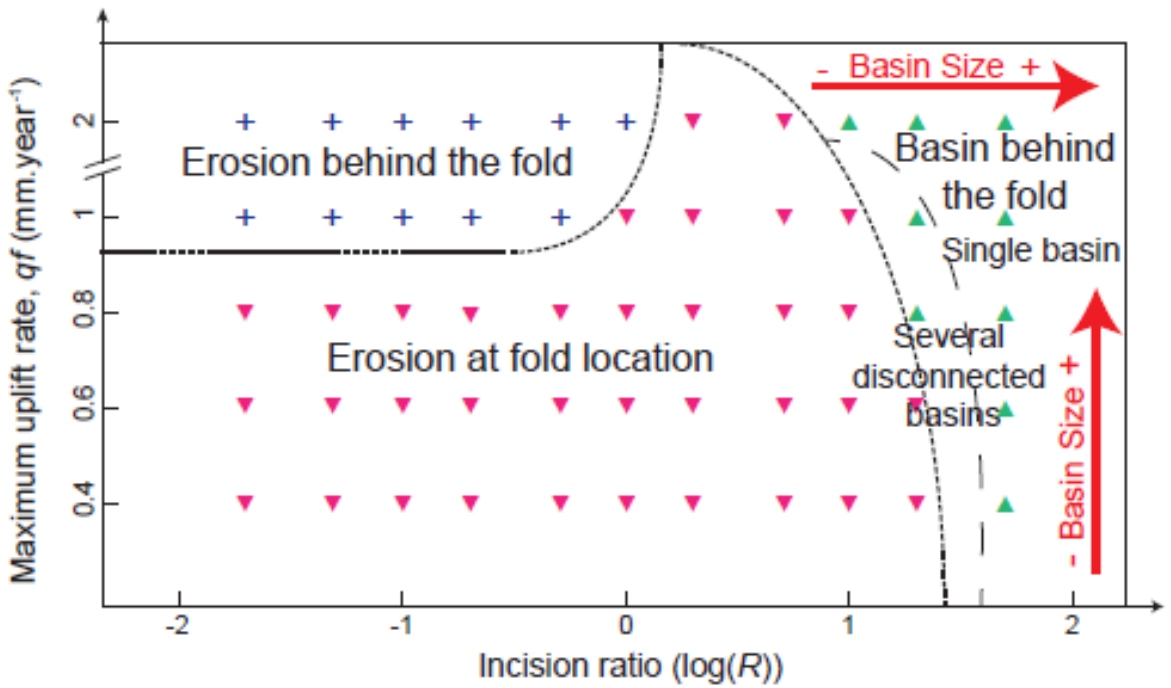

v "Maximum of erosion at the fold location" mode

+ "Maximum of erosion behind the fold" mode

^ "Basin behind the fold" mode

Figure 5: A. Distribution of the different drainage network modes for different conditions of uplift and incision ratio (Transverse mode: full green circle, Intermediate mode: brown square, Parallel mode: yellow diamonds). B. Distribution of the different erosion and sedimentation modes for different conditions of uplift and incision ratio (Erosion at fold location mode: full pink triangle, Erosion behind the fold mode: blue cross, Basin behind the fold mode: full green triangle). The dotted thick lines represent the transition from one mode to another and have been constrained by numerical simulations, taken after $1 \mathrm{Ma}$. The dotted thin lines represent slight variation within a mode (here the number of wind gaps or river incision). W.G.: refers to wind gaps, and I. to incision of transverse rivers. Each point represents a numerical simulation. 
A. $q f=0.6 \mathrm{~mm} \cdot \mathrm{yr}^{-1} R=0.05$
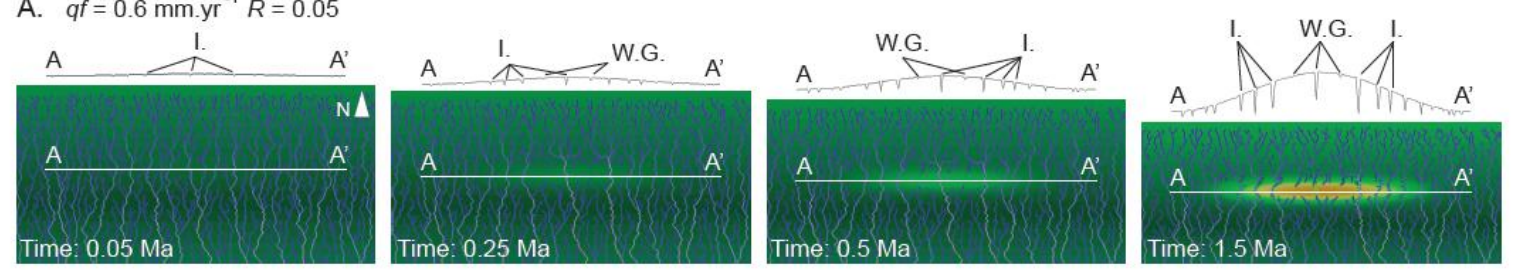

B. $q f=0.6 \mathrm{~mm} \cdot \mathrm{yr}^{-1} R=20$
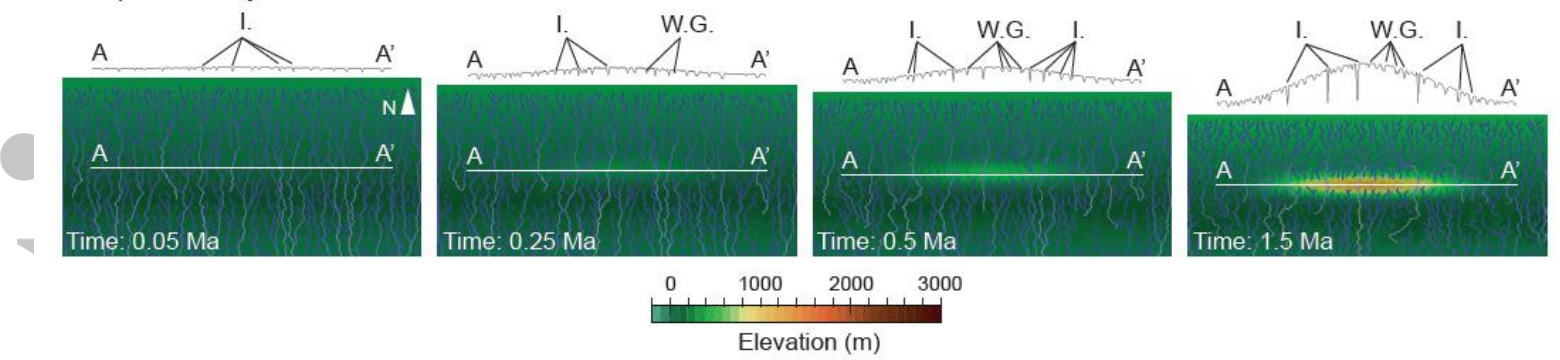

\begin{tabular}{rl}
0 & 1000,2000 \\
\hline
\end{tabular}

Figure 6: Evolution through time of the drainage network and topographic elevation for $\mathbf{A}$. $R=0.05$ and $\mathbf{B} . R=20$. Transects $A A^{\prime}$ indicate the position of the vertical profile of the folds. W.G. refers to wind gap while I. refers to incision of transverse streams. For visualisation the vertical axis of the profile has been amplified 10 times.

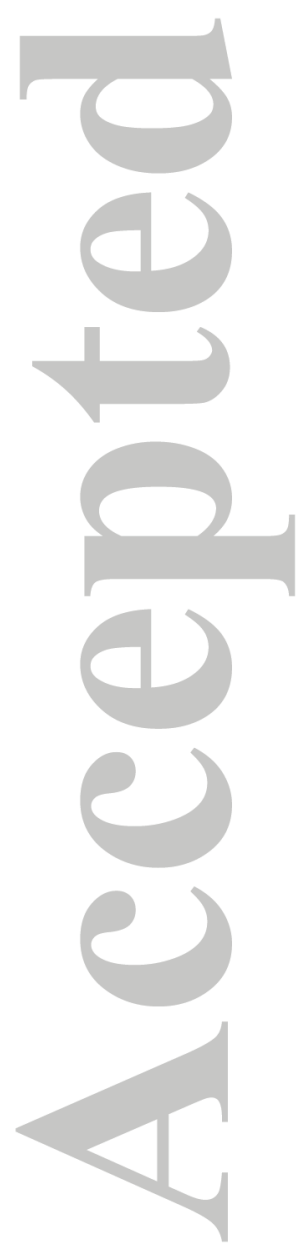


A. $q f=0.6 \mathrm{~mm} \cdot \mathrm{yr}^{-1} R=0.05$
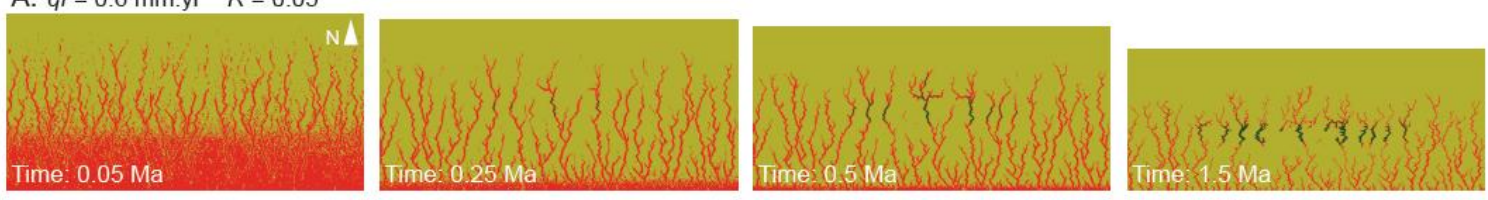

B. $q f=0.6 \mathrm{~mm} \cdot \mathrm{yr}^{-1} R=20$

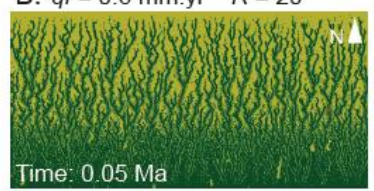

Deposited sediments
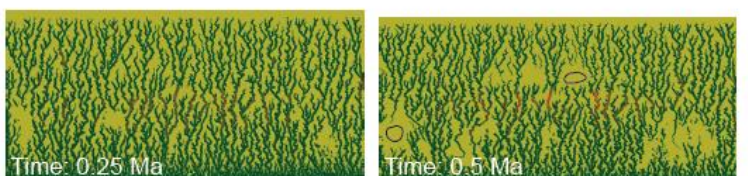

Soft "shale-like" lithology

Resistant "carbonate-like" lithology

$\bigcirc$ Large sediment depocenters (> $50 \mathrm{~m}$ in thickness)

Figure 7: Evolution through time of the exposed lithologies for $\mathbf{A} . \mathbf{R}=0.05$ and $\mathbf{B}$. $\mathbf{R}=20$.
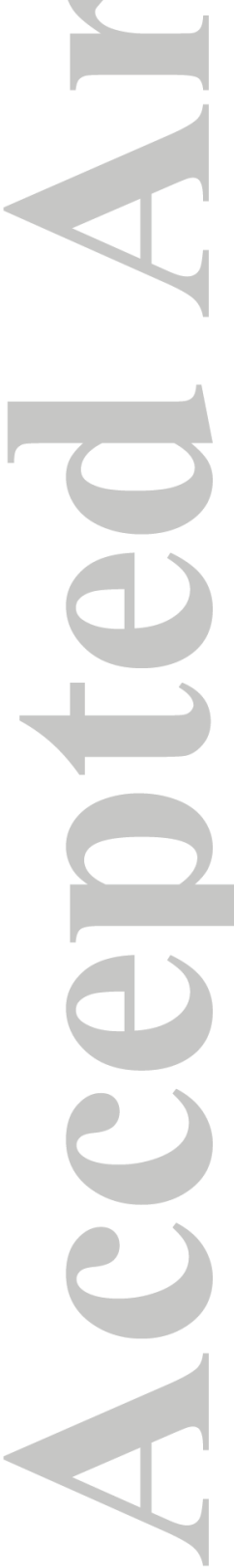
A. $R=0.05 \quad \sigma=0.125 \mathrm{Ma}$

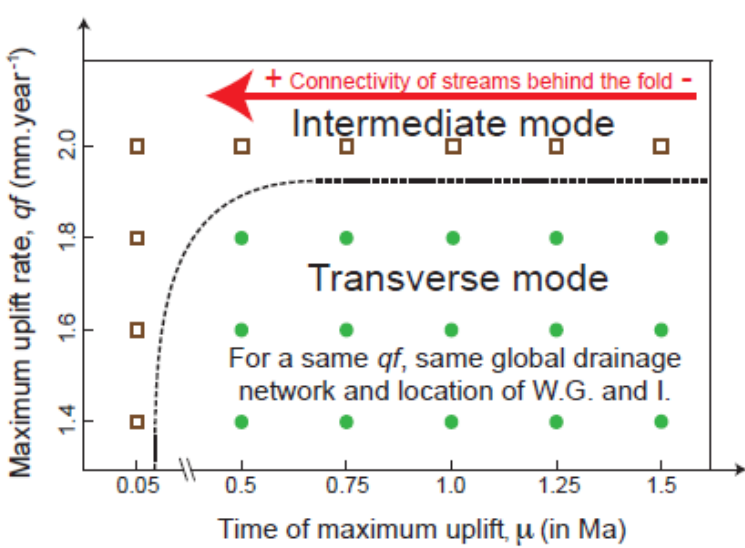

C. $R=0.05 \quad \sigma=0.125 \mathrm{Ma}$

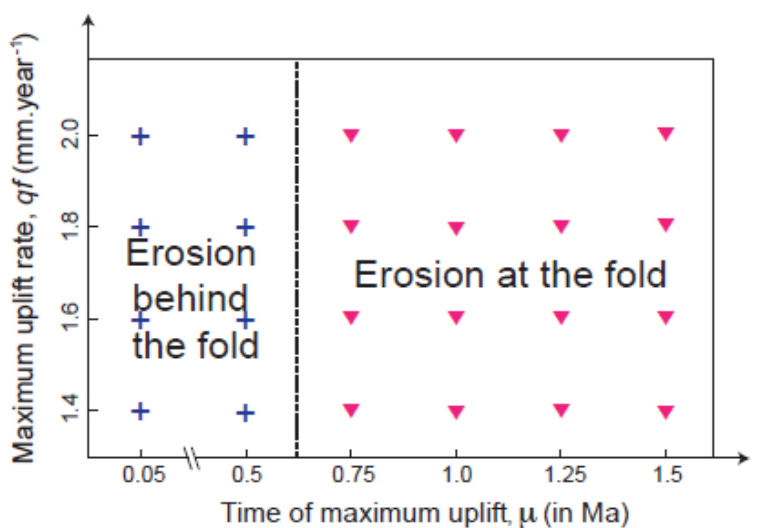

B. $R=20 \quad \sigma=0.125 \mathrm{Ma}$

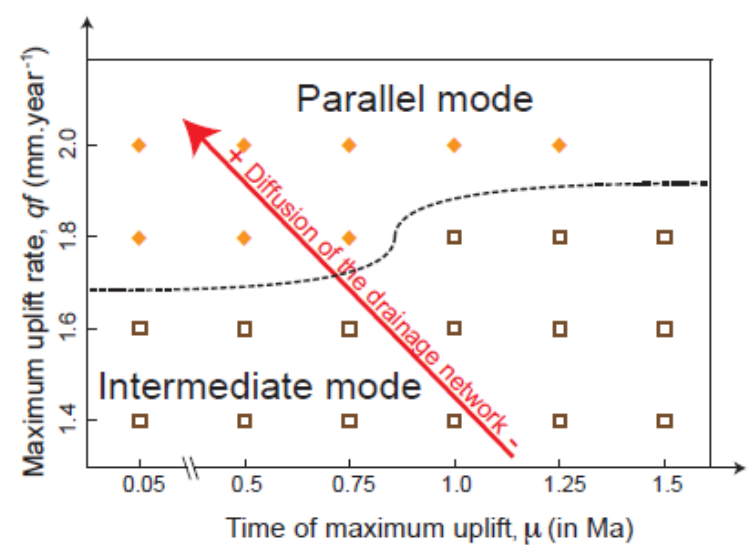

D. $R=20 \quad \sigma=0.125 \mathrm{Ma}$

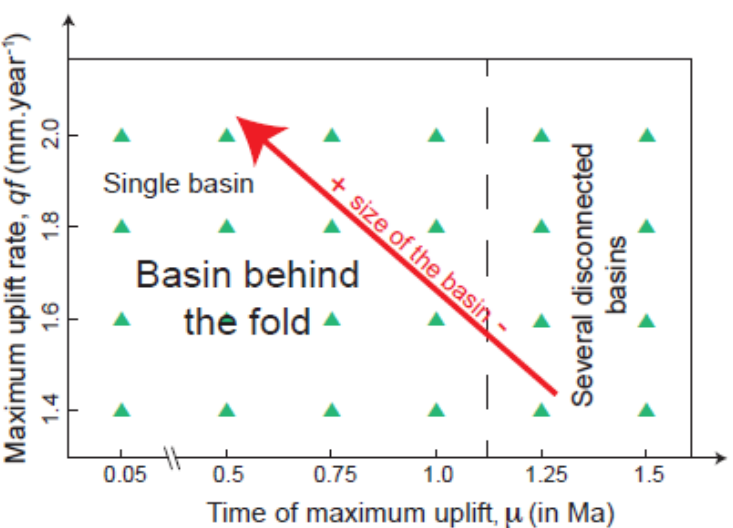

\section{- Transverse mode \\ 口 Intermediate mode \\ - Parallel mode}

v "Maximum of erosion at the fold location" mode

+ "Maximum of erosion behind the fold" mode

s "Basin behind the fold" mode

Figure 8: Distribution of the different drainage network modes for different conditions of maximum fold crest uplift, qf and time of maximum uplift, $\mu$ for $\mathbf{A}$. the case where $R=0.05$, and $\mathbf{B}$. the case where $R$ $=20$ (Transverse mode: full green circle, Intermediate mode: brown square, Parallel mode: yellow diamonds). Distribution of the different erosion and sedimentation modes for different conditions of maximum fold crest uplift, qf and time of maximum uplift, $\mu$ for $\mathbf{C}$. the case where $R=0.05$, and $\mathbf{D}$. the case where $R=20$ (Erosion at fold location mode: full pink triangle, Erosion behind the fold mode: blue cross, Basin behind the fold mode: full green triangle). In all the simulations, $\sigma=0.125 \mathrm{Ma}$. The dotted thick lines represent the transition from one mode to another and have been constrained by the numerical simulations, taken after $2 \mathrm{Ma}$. The dotted thin lines represent slight variation within a mode. Each point represents a numerical simulation. 


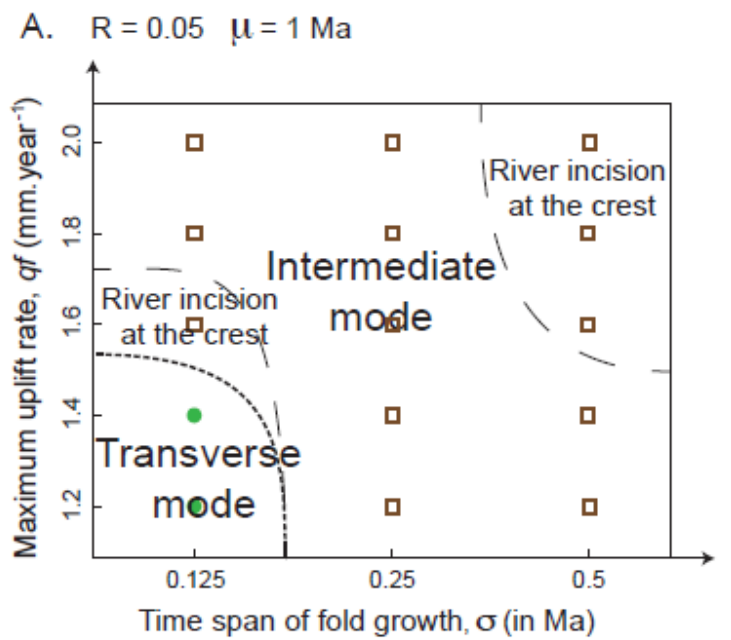

B. $\mathrm{R}=20 \mu=1 \mathrm{Ma}$

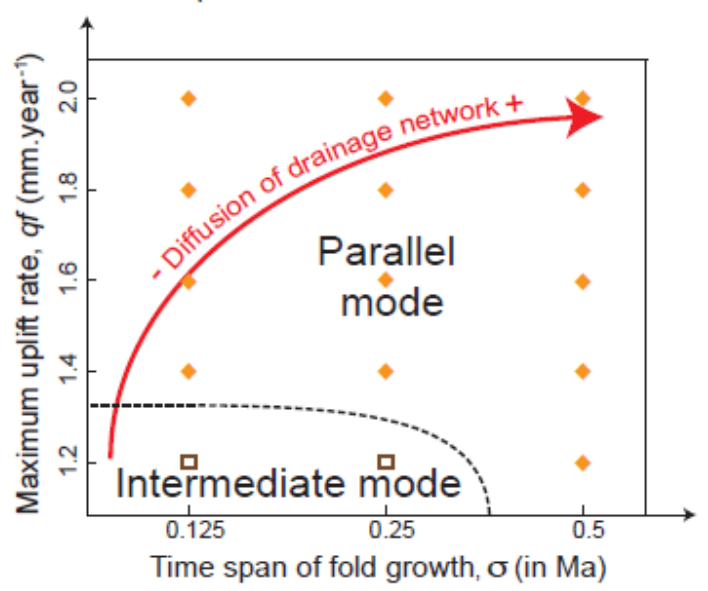

C. $\mathrm{R}=0.05 \mu=1 \mathrm{Ma}$

D. $\mathrm{R}=20 \mu=1 \mathrm{Ma}$
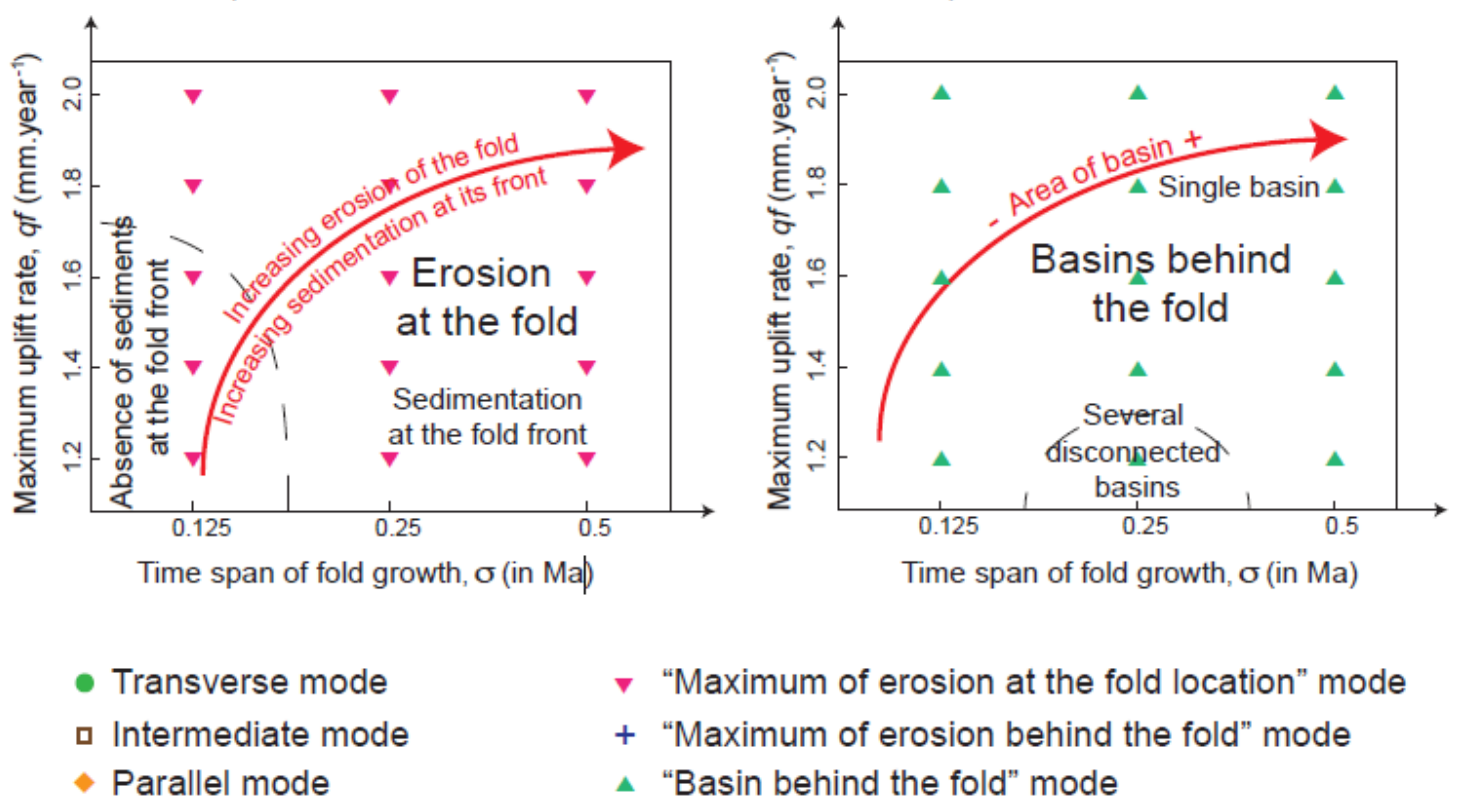

v "Maximum of erosion at the fold location" mode

+ "Maximum of erosion behind the fold" mode

$\Delta$ "Basin behind the fold" mode

Figure 9: Distribution of the different drainage network modes for different conditions of maximum fold crest uplift, $q f$ and time span of fold growth, $\sigma$ for $\mathbf{A}$. the case where $R=0.05$, and $\mathbf{B}$. the case where $R=20$ (Transverse mode: full green circle, Intermediate mode: brown square, Parallel mode: yellow diamonds). Distribution of the different erosion and sedimentation modes for different conditions of maximum fold crest uplift, $q f$ and time span of fold growth, $\sigma$ for $\mathbf{C}$. the case where $R=0.05$, and $\mathbf{D}$. the case where $R=20$ (Erosion at fold location mode: full pink triangle, Erosion behind the fold mode: blue cross, Basin behind the fold mode: full green triangle). In all the simulations, $\mu=1 \mathrm{Ma}$. The dotted thick lines represent the transition from one mode to another and have been constrained by the numerical simulations, taken after $2 \mathrm{Ma}$. The dotted thin lines represent slight variation within a mode. Each point represents a numerical simulation.

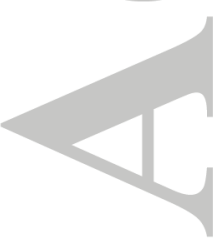

This article is protected by copyright. All rights reserved. 

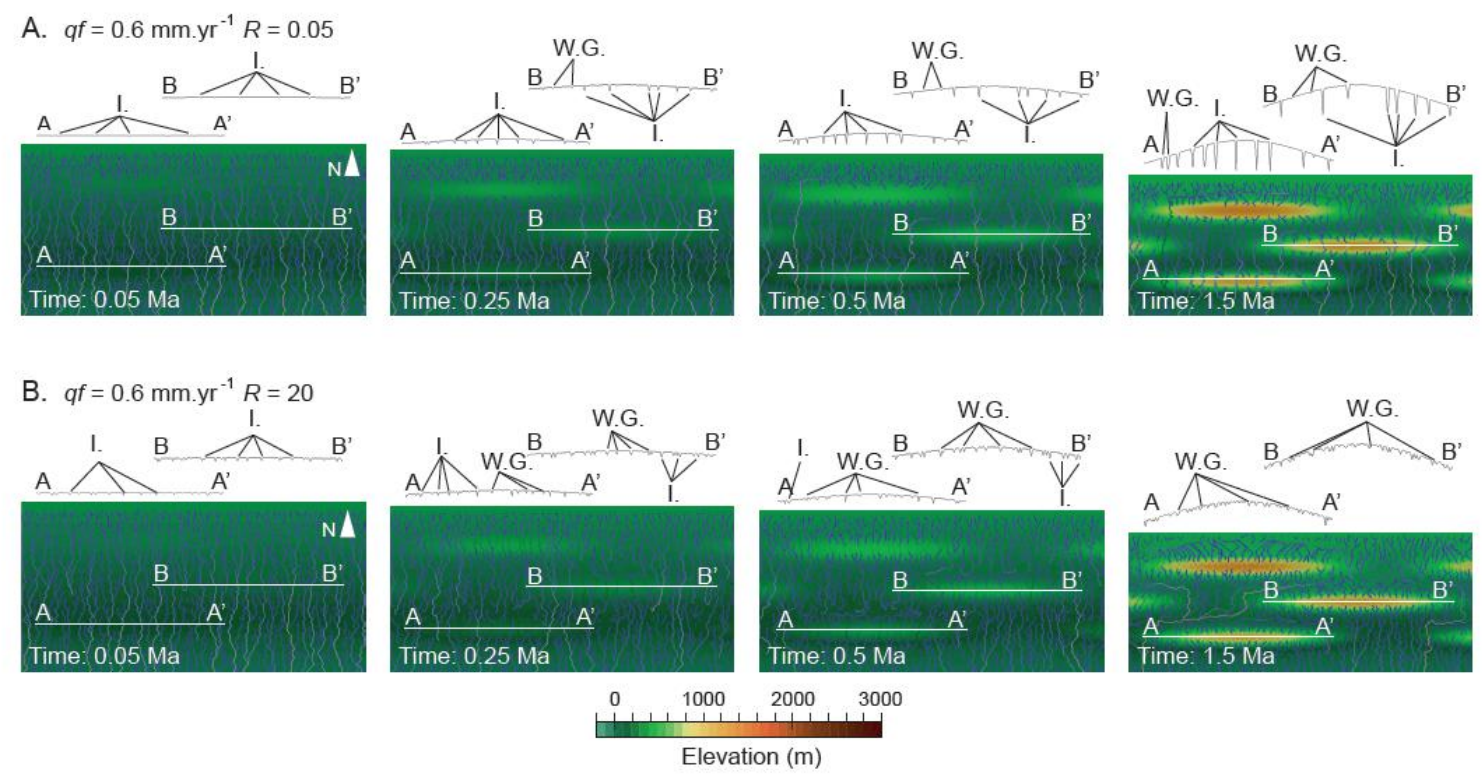

Figure 10: Evolution through time of the drainage network and topographic elevation for a model with three folds and for $\mathbf{A}$. $R=0.05$ and $\mathbf{B} . R=20$. Transects $A A^{\prime}$ indicate the position of the vertical profile of the folds. W.G. refers to wind gap while I. refers to incision of transverse streams. For visualisation the vertical axis of the profile has been amplified 10 times.

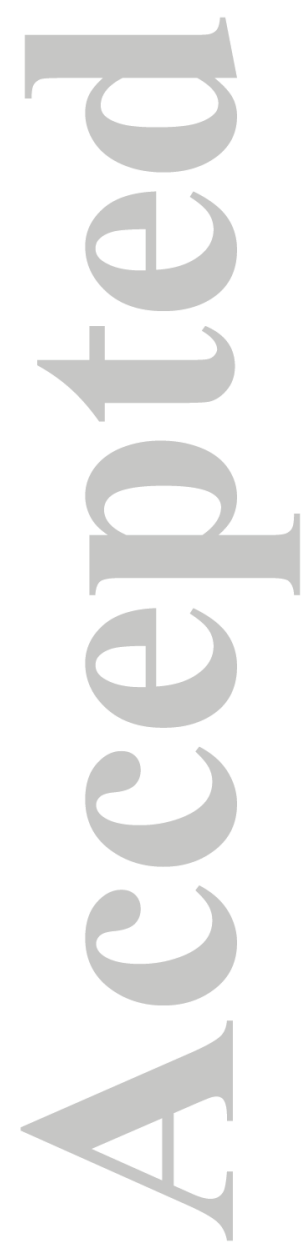


A. $q f=0.6 \mathrm{~mm} \cdot \mathrm{yr}^{-1} R=0.05$
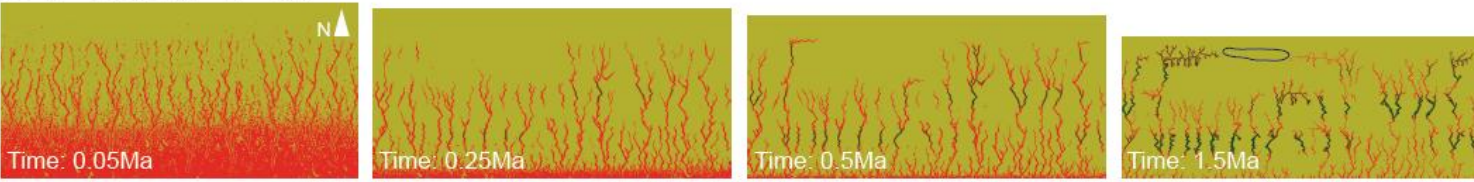

B. $q f=0.6 \mathrm{~mm} \cdot \mathrm{yr}^{-1} R=20$
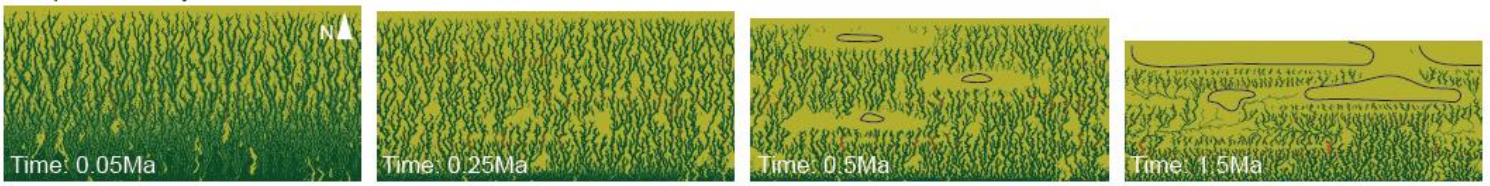

Deposited sediments

Soft "shale-like" lithology

Resistant "carbonate-like" lithology

$\bigcirc$ Large sediment depocenters (> $50 \mathrm{~m}$ in thickness)

Figure 11: Evolution through time of the exposed lithologies for $\mathbf{A} . \mathrm{R}=0.05$ and $\mathbf{B} . \mathrm{R}=20$.

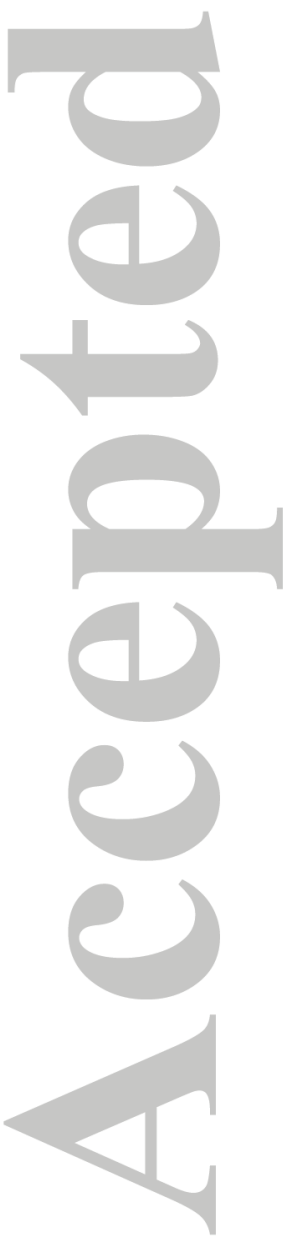



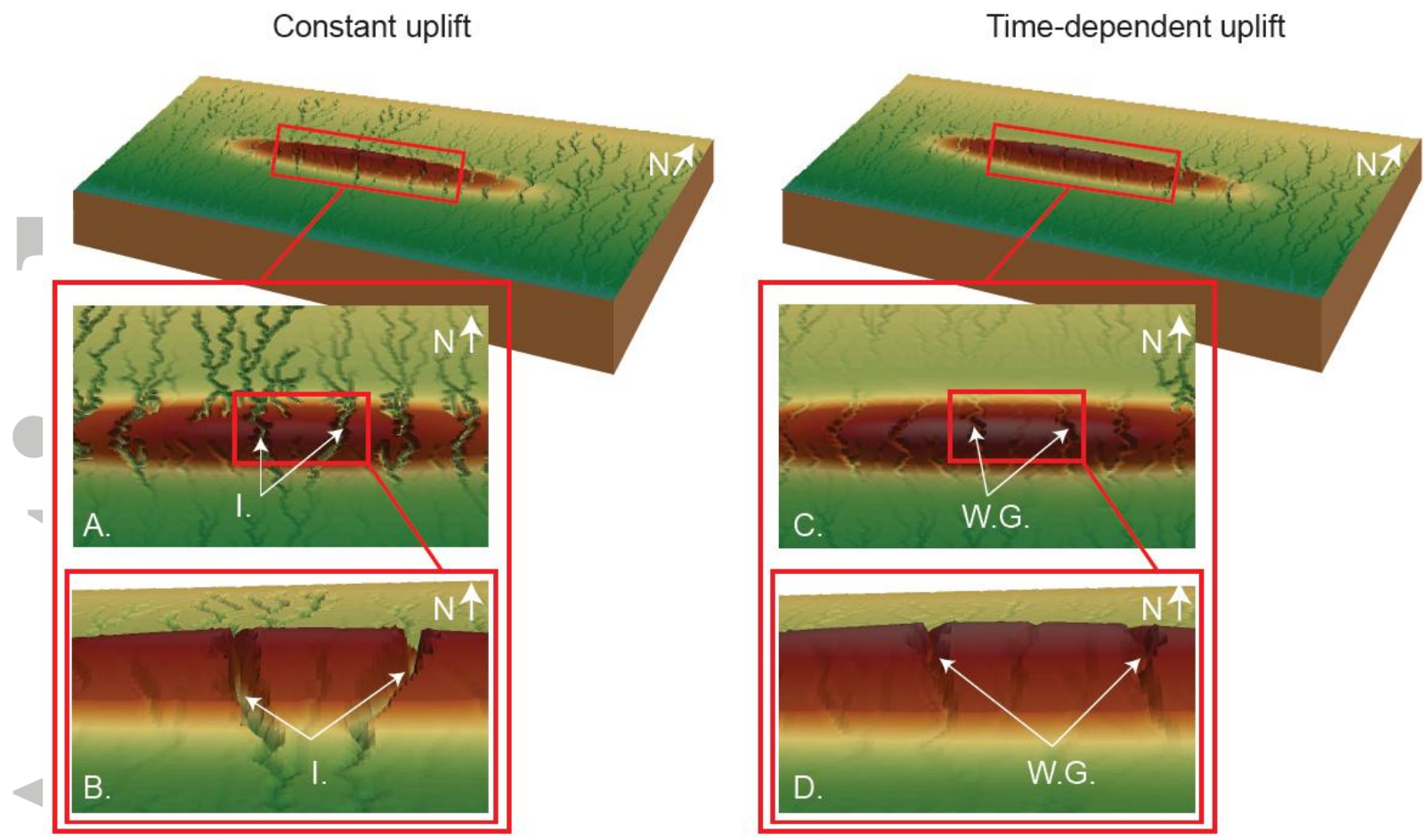

Figure 12: 3D visualization of two models with the same total uplift but for two different fold growth rate. A-B. Constant fold growth rate, $q f=0.6 \mathrm{~mm} . \mathrm{yr}^{-1}$ C-D. Variable uplift through time with $q f_{\text {gauss }}=$ $1.8 \mathrm{~mm}_{\mathrm{yr}}{ }^{-1}, \sigma=0.25 \mathrm{Ma}$, and $\mu=1 \mathrm{Ma}$. A. and C. Top view of the anticline. B. and $\mathbf{D}$. view of the anticline south face. W.G.: refers to wind gaps, and I. to incision of transverse rivers. 


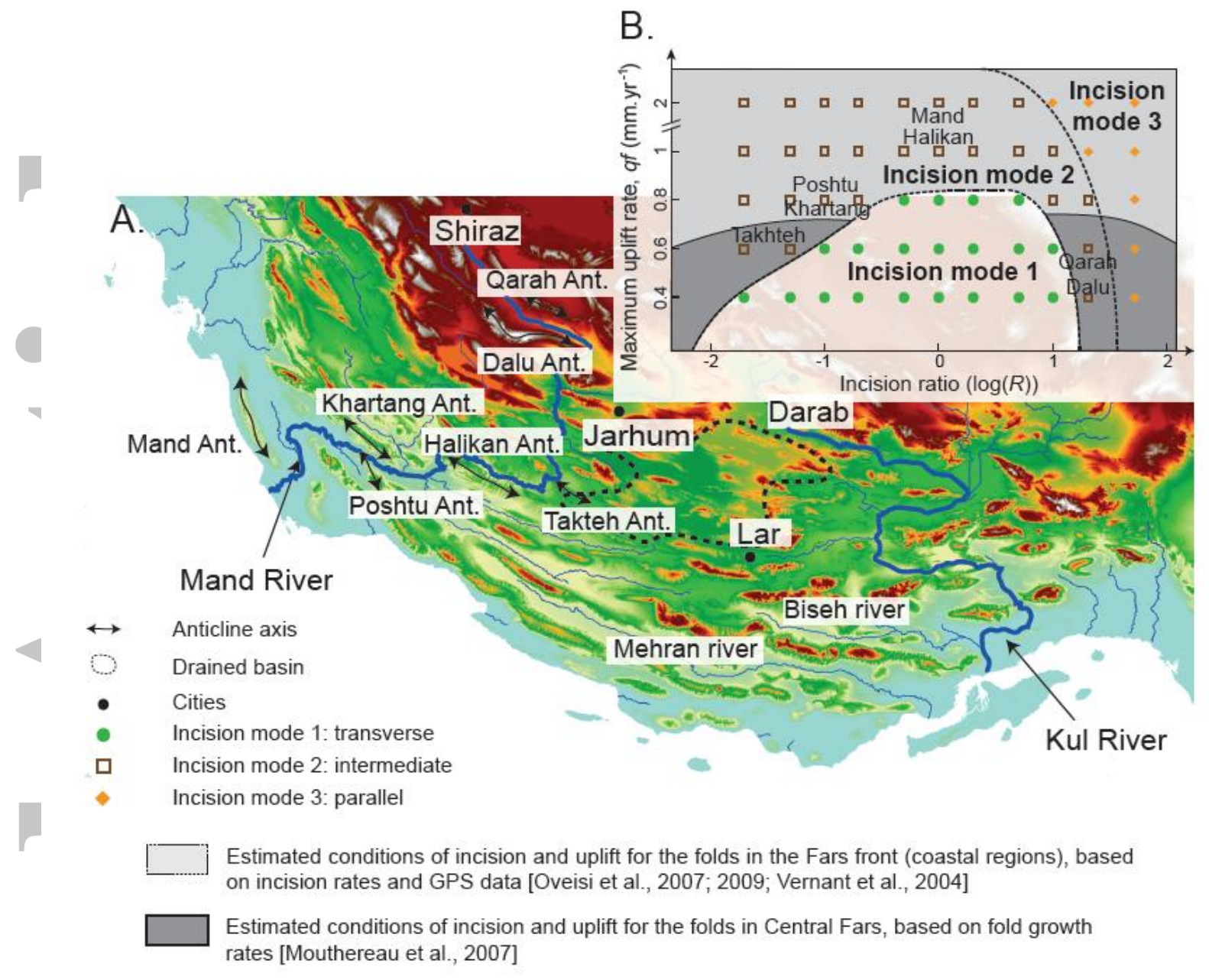

Figure 13: A. Digital Elevation Model of the Fars Province and drainage network. The anticlines plotted in B. and the internal drained basins are localized on the DEM. B. Conditions of uplift and incision ratio for several anticlines in the Fars Province, based on numerical experiments and fold growth rate available in the literature. 